\title{
Synthesis of Novel Derivatives of Carbazole-Thiophene, Their Electronic Properties, and Computational Studies
}

\author{
E. F. Damit, ${ }^{1}$ N. Nordin, ${ }^{1}$ A. Ariffin, ${ }^{1}$ and K. Sulaiman ${ }^{2}$ \\ ${ }^{1}$ Chemistry Department, Science Faculty, University of Malaya, 50603 Kuala Lumpur, Malaysia \\ ${ }^{2}$ Physic Department, Science Faculty, University of Malaya, 50603 Kuala Lumpur, Malaysia \\ Correspondence should be addressed to A. Ariffin; azhar70@um.edu.my
}

Received 10 January 2016; Accepted 6 April 2016

Academic Editor: Davut Avci

Copyright (C) 2016 E. F. Damit et al. This is an open access article distributed under the Creative Commons Attribution License, which permits unrestricted use, distribution, and reproduction in any medium, provided the original work is properly cited.

\begin{abstract}
A series of carbazole-thiophene dimers, P1-P9, were synthesized using Suzuki-Miyaura and Ullmann coupling reactions. In P1P9, carbazole-thiophenes were linked at the N-9 position for different core groups via biphenyl, dimethylbiphenyl, and phenyl. Electronic properties were evaluated by UV-Vis, cyclic voltammogram, and theoretical calculations. Particularly, the effects of conjugation connectivity on photophysical and electrochemical properties, as well as the correlation between carbazole-thiophene and the core, were studied. Carbazole connecting with thiophenes at the 3,6-positions and the phenyl group as a core group leads to increased stabilization of HOMO and LUMO energy levels where the bandgap $(\Delta E)$ is significantly reduced.
\end{abstract}

\section{Introduction}

Organic photovoltaics (OPVs) are alternatives to amorphous silicon as materials for thin film solar cells. Photovoltaics with small molecule-based active layers possess several potential advantages over polymer systems. Compared to polymers, small molecules do not suffer from the effects of polydispersity, tend to have less batch-to-batch variation, and are easily functionalized and purified via standard techniques [1].

$\pi$-Conjugated oligomers and polymers have attracted much attention in recent decades due to their potential uses as semiconductors and electroactive materials in various organic electronic devices such as organic field-effect transistors (OFETs), organic light emitting diodes (OLEDs), organic solar cells (OSCs), and nonlinear optical devices [211]. These oligomers have an advantage in terms of convenient fine-tuning of electronic, photophysical, and electrochemical properties by rational structural modification to achieve optimal device performance. Moreover, $\pi$-conjugated oligomers with sophisticated functionalities are now key components in molecular electronics [12, 13].

Carbazole has fine optical properties, a low redox potential, and high chemical stability; thus, oligo/polycarbazoles have served as representative benchmark materials in OFETs,
OLEDs, and OSCs [14-18]. Poly(3,6-carbazole)s and 3,6functionalized carbazoles have been extensively studied over the past few decades because carbazole groups can be easily functionalized by electrophilic substitution at its 3- and 6positions (para positions from the nitrogen atom) due to of their high electron density. In this context, carbazoles can be regarded as important scaffolds for the construction of $\pi$-functional materials because of their rich diversity in structural modification. Oligothiophenes, particularly $\alpha$ oligothiophenes, are among the most intensively investigated organic compounds for a variety of materials applications $[19,20]$. Hence, mixed $\pi$-conjugated oligomers composed of carbazole and thiophene moieties have recently attracted considerable attention from the viewpoint of their potential as the active component of organic electronics and their synthetic accessibility. Various carbazole-thiophene hybrid oligomers that are used as functional materials by using their fluorescence and donor properties have been reported [21$25]$; in particular, a large number of derivatives possessing the anchoring and acceptor groups used for OSCs have been recently synthesized since the pioneering work by Koumura, Hara, and coworkers [26-32]. However, less attention has been given to the clarification of the structure property relationships in the carbazole-thiophene-based $\pi$-system, 
which are indispensable for materials design. Recently a large series of thienyl-substituted carbazole derivatives (thienylcarbazoles) were synthesized, and the effects of the connection between the carbazole and thiophene moieties on the photophysical and electrochemical properties were investigated [18]. Studies have shown that both vapor and solution-based deposition of small molecules can lead to efficient multilayer or bulk heterojunction $(\mathrm{BJH})$ devices, suggesting the importance of the final film microstructure, rather than fabrication techniques, on device performance [33]. Because the mobility of the charge carrier depends on the molecular ordering and hence the degree of crystallinity [34], small molecules may have the advantage of higher charge carrier mobilities. Despite recent efforts to characterize the morphology of small molecule BHJs $[35,36]$ knowledge regarding these systems is still lacking. In the current study, a series of thienylcarbazoles were prepared and detailed theoretical and experimental investigation of the molecular planarity influenced by the degree of conjunction at different types of cores and how this property impacts $E_{\text {gap }}$ by investigating individual $E_{\text {LUMO }}$ and $E_{\text {HOMO }}$ were carried out.

Here, the synthesis, structural features, and electronic and photophysical properties of P4-P9 (Figure 1) according to UV-Vis, fluorescence spectroscopy, cyclic voltammetry, and theoretical calculations in comparison with reported compounds P1-P3 are described.

\section{Results and Discussion}

2.1. Synthesis. The synthesis of compounds P1-P9 was described in three parts as outlined in Schemes 1 and 2. The key steps in the synthesis of the compounds involved Suzuki-Miyaura [37] and Ullmann coupling [38] reactions. The detailed procedures for the synthesis of the compound are described in Section 4.

The Ullmann coupling reaction was performed on carbazole (1) with either 4,4-diiodobiphenyl (2), 4,4-diiodo- $2^{\prime} 2$ dimethyl-1,1-biphenyl (3), or 1,4-diiodobenzene (4) to give P1, P2, and P3 in 50\%, 60\%, and 80\% yields, respectively. Compounds P1 (CBP) [39, 40], P2 (CDBP) [41], and P3 (BCP) $[39,40]$ are known compounds.

The syntheses of compounds P4, P5, and P6 were achieved in three steps starting from carbazole (1) as described in Scheme 1. The first step involved iodination of $\mathbf{1}$ using 0.5 eq of iodine to give 3 -iodocarbzole (5). This was followed by Suzuki-Miyaura cross coupling of 5 with thiophene2-boronic acid pinacol ester (6) to produce monothienylsubstituted carbazole (7). Ullmann coupling of compound 7 with compounds 2, 3, and 4 afforded compounds P4, P5, and P6 in 26\%, 35\%, and 48\% yields, respectively.

In a similar approach, compounds P7, P8, and P9 were synthesized in three steps from compound $\mathbf{1}$ as described in Scheme 2. Iodination of compound 1 using 1 eq of iodine gave 3,6-diiodocarbazole (8), which was then refluxed with compound 6 to give dithienyl-substituted carbazole (9). Ullmann coupling of $\mathbf{9}$ with $\mathbf{2 , 3}$, and $\mathbf{4}$ gave compounds P7, P8, and P9 in 75\%, 60\%, and 50\% yields, respectively. All of the compounds were fully characterized by spectroscopic methods such as ${ }^{1} \mathrm{H} \mathrm{NMR},{ }^{13} \mathrm{C} \mathrm{NMR}$, and mass spectroscopy.
2.2. Electronic Absorption Spectroscopy. The UV-Vis absorption spectra of P1-P9 were measured in DMF solutions (Figures 3(a), 3(b), and 3(c)), and the $\lambda_{\max }{ }^{\text {abs }}$ values for quantifying the extent of $\pi$-conjugation are summarized in Table 1 . It is clearly observed from Figures 2(a)-2(c) that the maximum absorption peak shifts to a longer wavelength as the number of thiophene groups increases. The absorption bands of all of the compounds were gradually red-shifted, when the thiophene group was connected to the carbazole at the 3 - and 6-positions and the extent of $\pi$-conjugation in the compounds increased, as expected. Compounds P4, P5, P6, P7, P8, and P9 show the longest wavelength absorptions at $377,373,372,390,393$, and $414 \mathrm{~nm}$, respectively (Figure 2), which were considerably red-shifted in comparison to those of compounds P1, P2, and P3. For compounds P7, P8, and P9, we noted a maximum absorption wavelength at a higher absorbance, indicating that the attachment of thiophene groups at the 3-and 6-positions of the carbazole with a phenyl group core significantly enhances the optical properties (Figure 3(c)). Furthermore, the slight shift of wavelength for a fixed number of thiophene groups, bridging biphenyl groups, dimethylbiphenyl, and phenyl suggests that the differences in core groups in the compounds affect the optical properties. Noticeably, $\lambda_{\max }$ abs are not affected by the changes of core groups (Figures 3(a)-3(c)).

It is well known that $\pi$-conjugated thiophene oligomers and polymers tend to $\pi$-stack because of the strong intermolecular interaction between $\pi$-electrons [27]. The difference in intermolecular $\pi-\pi$ interaction for these compounds would account for the differences in the broadness of their UV-Vis absorption spectra, as shown in Figure 2. We also observe that the broadness increased slightly as the numbers of thiophene groups increased [44].

It is well known that $\pi$-conjugated thiophene oligomers and polymers tend to $\pi$-stack due to the strong intermolecular interaction between $\pi$-electrons [27]. The difference of intermolecular $\pi-\pi$ interaction for these compounds would account for their different broadness of UV-Vis absorption spectra, as shown in Figure 3. We also observe that the broadness increased slightly with the increasing number of thiophenes [44].

All the compounds P1-P9 are fluorescent. After the functionalization of the carbazole groups, the fluorescence maxima $\left(\lambda_{\mathrm{em}}\right)$ gradually red-shifted upon the addition of thiophene group, resulting in a significant red shift in the emission spectrum as shown in Figures 4(a)-4(c), and the spectral data are summarized in Table 1 . The broad absorption band in the fluorescence spectra of P4, P5, P6, P7, P8, and P9 suggest the contribution of a more rigid structure in the excited state, namely, the quinoid state, than the ground state [45]. In contrast to the absorption, we note that the emission of $\mathbf{P 1}$ is redshifted compared to $\mathbf{P} 2$ and $\mathbf{P 3}$, which is attributed to the planarization of $\mathbf{P 1}$ after the transition state to the excited state. Such a geometric relaxation is not possible for $\mathbf{P} \mathbf{2}$ due to the bulkier side on the introduction of methyl group at core group (Figure 5(a)) [46]. Similarly, P4 is red-shifted compared to P5 and P6 (Figure 5(b)). As the attachment of thiophene at 3and 6- on the carbazole for P7, P8, and P9, $\lambda_{\mathrm{em}}$ are not significantly affected by the change of core groups (Figure 5(c)). 
Journal of Chemistry

3<smiles>c1ccc2c(c1)c1ccccc1n2-c1ccc(-c2ccc(-n3c4ccccc4c4ccccc43)cc2)cc1</smiles><smiles>Cc1cc(-n2c3ccccc3c3ccccc32)ccc1-c1ccc(-n2c3ccccc3c3ccccc32)cc1C</smiles><smiles>c1ccc2c(c1)c1ccccc1n2-c1ccc(-n2c3ccccc3c3ccccc32)cc1</smiles><smiles>c1csc(-c2ccc3c(c2)c2ccccc2n3-c2ccc(-c3ccc(-n4c5ccccc5c5cc(-c6cccs6)ccc54)cc3)cc2)c1</smiles><smiles>Cc1cc(-n2c3ccccc3c3cc(-c4cccs4)ccc32)ccc1-c1ccc(-n2c3ccccc3c3cc(-c4cccs4)ccc32)cc1C</smiles>

Pu

P5<smiles>c1csc(-c2ccc3c(c2)c2ccccc2n3-c2ccc(-n3c4ccccc4c4cc(-c5cccs5)ccc43)cc2)c1</smiles>

PG<smiles>Cc1cc(-n2c3ccc(-c4cccs4)cc3c3cc(-c4cccs4)ccc32)ccc1-c1ccc(-n2c3ccc(-c4cccs4)cc3c3cc(-c4cccs4)ccc32)cc1C</smiles><smiles>c1csc(-c2ccc3c(c2)c2cc(-c4cccs4)ccc2n3-c2ccc(-n3c4ccc(-c5cccs5)cc4c4cc(-c5cccs5)ccc43)cc2)c1</smiles>

Figure 1: Structures of compounds. 


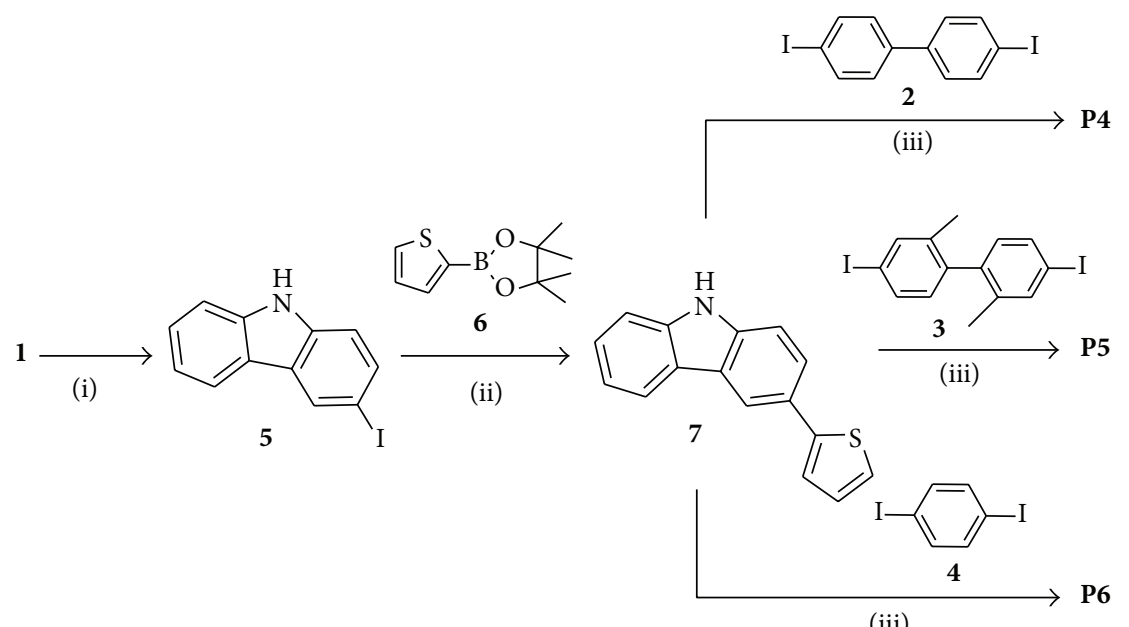

(iii)

Scheme 1: Synthesis of P4, P5, and P6. (i) $\mathrm{I}_{2}$ (0.5 eq), $\mathrm{AcOH}$, and reflux. (ii) $\left.\mathrm{K}_{2} \mathrm{CO}_{3}, \mathrm{Pd}_{\left(\mathrm{PPh}_{3}\right.}\right)_{4}$, EtOH, and reflux for $24 \mathrm{~h}$. (iii) $\mathrm{K}_{2} \mathrm{CO}_{3}$, copper powder, 18-crown-6, $o$-DCB, and reflux.

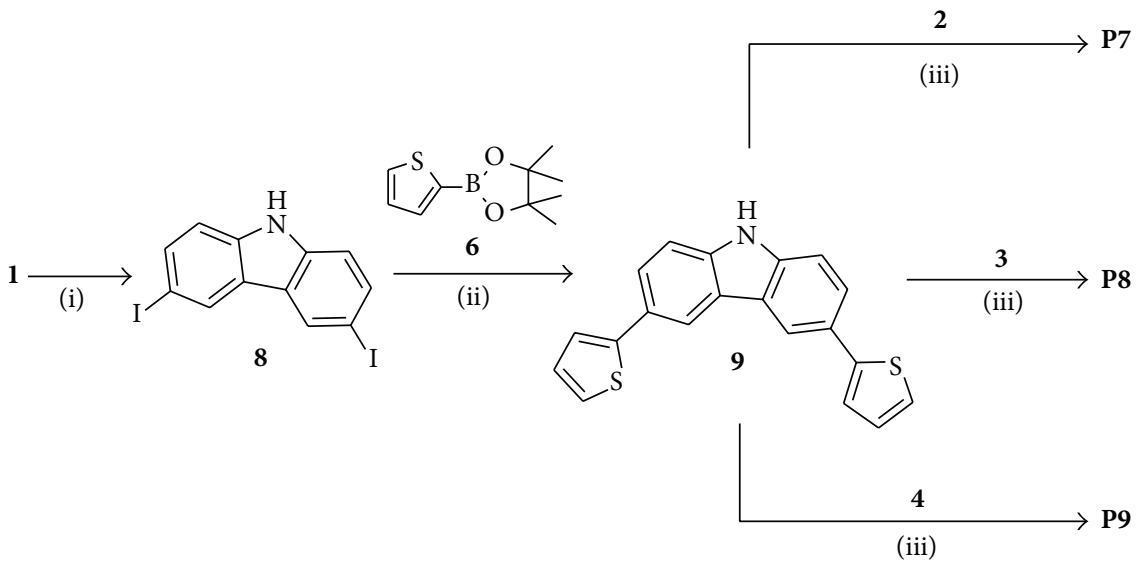

Scheme 2: Synthesis of P7, P8, and P9. (i) $\mathrm{I}_{2}(1 \mathrm{eq}), \mathrm{AcOH}$, and reflux. (ii) $\mathrm{K}_{2} \mathrm{CO}_{3}, \mathrm{Pd}\left(\mathrm{PPh}_{3}\right)_{4}$, EtOH, and reflux for $24 \mathrm{~h}$. (iii) $\mathrm{K}_{2} \mathrm{CO}_{3}, \mathrm{Cu}_{\text {, }}$ 18-crown-6, $o$-DCB, and reflux.

TABLE 1: UV-Vis: spectroscopic data and fluorescence on $300 \mathrm{~nm}$ excitation $^{\mathrm{a}}$.

\begin{tabular}{lccc}
\hline & $\lambda_{\max }{ }^{\mathrm{abs}}(\mathrm{nm})$ & $\lambda_{\text {onset }}(\mathrm{nm})$ & $\lambda_{\mathrm{em}}{ }^{\mathrm{c}}(\mathrm{nm})$ \\
\hline P1 (CBP) & $293,317^{\mathrm{b}}, 340^{\mathrm{b}}$ & 360 & 390 \\
P2 & $293,328^{\mathrm{b}}, 341^{\mathrm{b}}$ & 353 & 351 \\
P3 & $293,326^{\mathrm{b}}, 340^{\mathrm{b}}$ & 352 & 355 \\
P4 & $301,325^{\mathrm{b}}$ & 377 & 413 \\
P5 & $293^{\mathrm{b}}, 303,322^{\mathrm{b}}$ & 373 & 396 \\
P6 & $294^{\mathrm{b}}, 303,324^{\mathrm{b}}$ & 372 & 394 \\
P7 & $318,344^{\mathrm{b}}$ & 390 & 412 \\
P8 & 313 & 393 & 410 \\
P9 & 316 & 414 & 519 \\
\hline
\end{tabular}

${ }^{\mathrm{a}}$ Measured in DMF. ${ }^{\mathrm{b}}$ Peak as shoulder. ${ }^{\mathrm{c}}$ Wavelength of the intensity maxima of the fluorescence at $300 \mathrm{~nm}$ excitation at room temperature.

Carbazole-thiophenes possess nonplanar structures in their ground state $\left(S_{0}\right)$ and become almost planar in the lowest state $\left(S_{1}\right)[47,48]$. This is expected because, with the addition of each thiophene group on P7, P8, and P9, these compounds are more conformationally flexible and thus produce a more diffuse spectrum [49]. The larger the number of $\pi$-electrons in a chromophore, the greater the shift to the red of the fluorescence and absorption spectra. Thus, the characteristics of a planar chromophore can be interpreted as being because, in this configuration, the number of functional $\pi$-electrons is a maximum [50].

2.3. Electrochemical Properties. To elucidate the effects of the degree of conjugation between the core, carbazole, and thiophene groups and the elongation of the molecular length on donor ability and electrochemical stability, cyclic voltammetry $(\mathrm{CV})$ was performed in a conventional three-electrode cell using a platinum working electrode, a platinum wire counter electrode, and a $\mathrm{Ag} / \mathrm{AgNO}_{3}$ reference electrode. In particular, the oxidation processes for P1-P9 were investigated in a DMF solution containing $0.05 \mathrm{~mol} \mathrm{~L}^{-1}$ of $\mathrm{n}-\mathrm{Bu}_{4} \mathrm{NPF}_{6}$ as a supporting electrolyte (Figure 6). The oxidation potential 


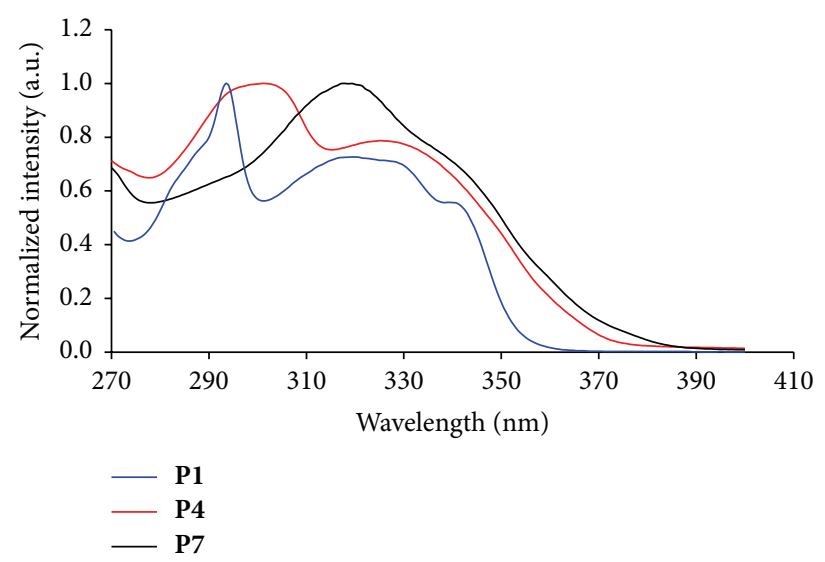

(a)

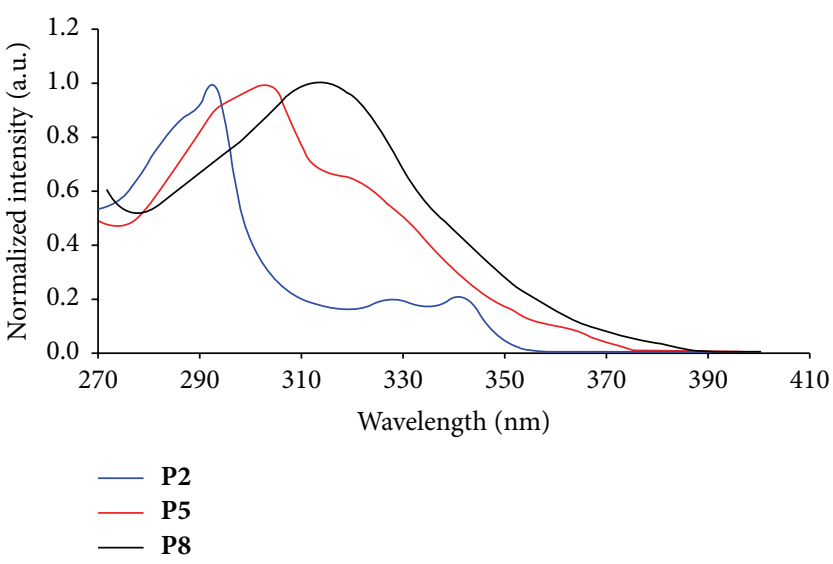

(b)

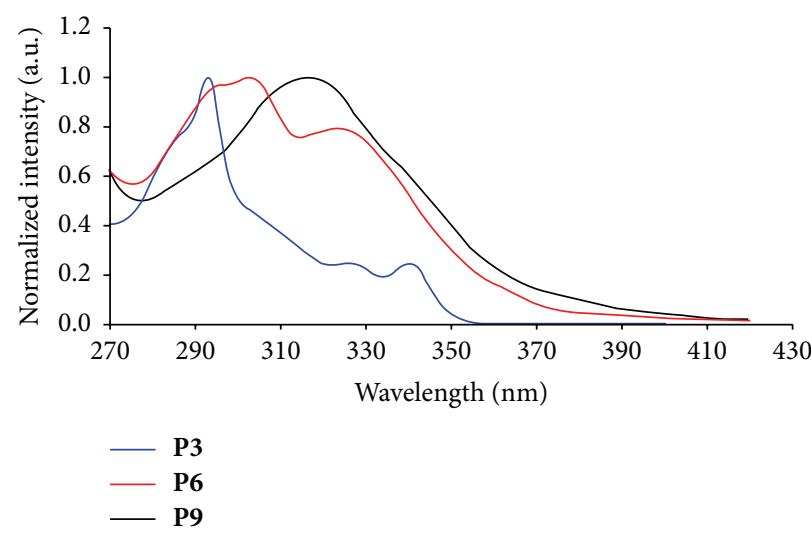

(c)

Figure 2: Electronic absorption spectra of (a) P1, P4, and P7; (b) P2, P5, and P8; and (c) P3, P6, and P9 recorded in DMF at $30^{\circ}$ C.

TABLE 2: Oxidation potential $\left(E_{\mathrm{pa}}\right)$ and onset $\left(E_{\text {onset }}\right)$ by cyclic voltammetry in DMF $\left(0.05 \mathrm{~mol} \mathrm{~L}^{-1} \mathrm{n}-\mathrm{Bu}_{4} \mathrm{NPF}_{6}\right)^{\mathrm{a}}$, and optical HOMO-LUMO gaps $\left(\Delta E_{\text {opt }}\right)^{\mathrm{b}}$.

\begin{tabular}{lccccc}
\hline & $E_{\mathrm{pa}}(\mathrm{V})$ & $E_{\text {onset }}(\mathrm{V})$ & $\mathrm{HOMO}^{\mathrm{c}}(\mathrm{eV})$ & $\mathrm{LUMO}^{\mathrm{d}}(\mathrm{eV})$ & -2.25 \\
\hline P1 & +1.04 & +0.89 & $-5.69,-5.63[41]$ & -2.18 & $3.44,3.47[41]$ \\
P2 & +1.13 & +0.90 & $-5.70,-5.64[41]$ & -2.09 & $3.52,3.51[41]$ \\
P3 & +1.04 & +0.82 & -5.62 & -2.41 & 3.53 \\
P4 & +1.16 & +0.90 & -5.70 & -2.56 & 3.29 \\
P5 & +1.41 & +1.09 & -5.89 & -2.60 & 3.33 \\
P6 & +1.44 & +1.14 & -5.94 & -2.54 & 3.34 \\
P7 & +1.28 & +0.92 & -5.72 & -2.69 & 3.18 \\
P8 & +1.38 & +1.05 & -5.85 & -2.99 & 3.16 \\
P9 & +1.44 & +1.19 & -5.99 & & 3.00 \\
\hline
\end{tabular}

${ }^{a}$ All potentials are given versus the $\mathrm{Fc}^{+} / \mathrm{Fc}$ couple used as the external standard; the scan rate is $100 \mathrm{mV} \mathrm{s}^{-1}$. ${ }^{\mathrm{b}}$ The values are obtained from UV/Vis absorption onset $\lambda_{\text {onset }}{ }^{\mathrm{c}}$ The values are those deduced from the $E_{\text {onset }}$ values according to the following equation: HOMO $=-\left(4.8+E_{\text {onset }}\right) \mathrm{eV}[42,43] .{ }^{\mathrm{d}}$ Estimated from the HOMO values and the optical band gap $\Delta E_{\text {opt }}$.

$\left(E_{\mathrm{pa}}\right)$ and onset $\left(E_{\text {onset }}\right)$ versus $\mathrm{Fc}^{+} / \mathrm{Fc}$ (ferrocenium/ferrocene couple) are listed in Table 2.

Noticeably, $E_{\mathrm{pa}}$ values for P4-P9 (Figures 6(b) and 6(c)) are cathodically shifted compared to those for P1, P2, and P3 (Figure 6(a)) by the subsequent addition of thiophene molecules, demonstrating that the connection with thiophene at the 3-and 6-positions of carbazole gives rise to high electrochemical stability and effectively enhances donor ability, which should result from the effective resonance stabilization of the cationic species [51].

The HOMO levels of the compound were estimated from the half-wave potential of the first oxidation relative to the ferrocene group. As the reduction peaks are out of our scan range, the LUMO levels were calculated by adding the 


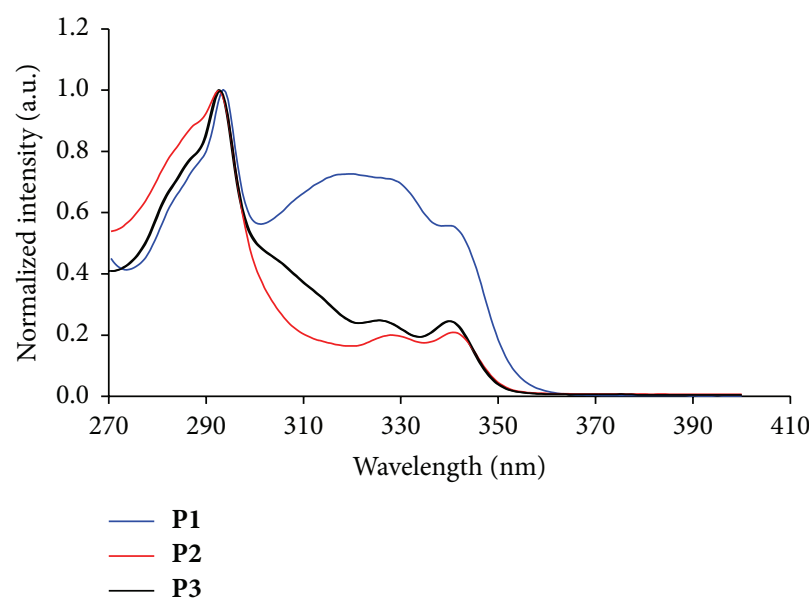

(a)

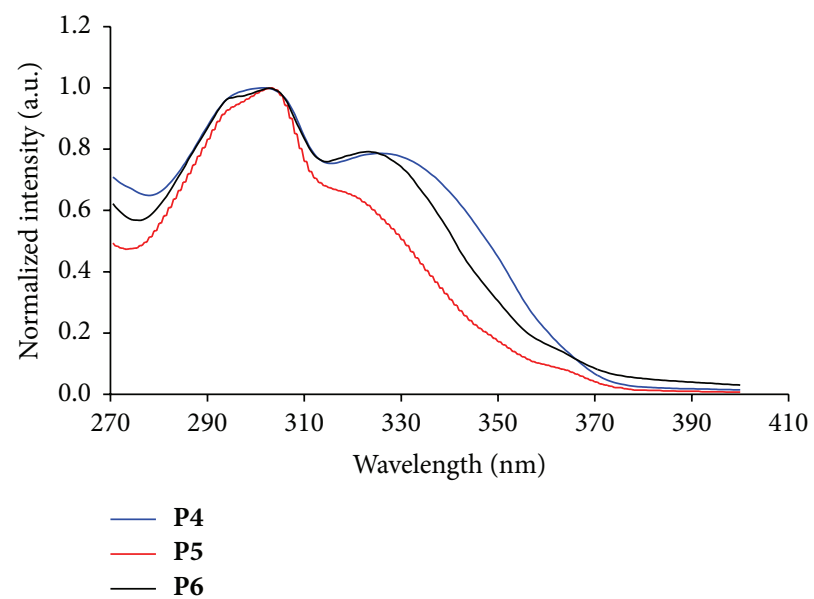

(b)

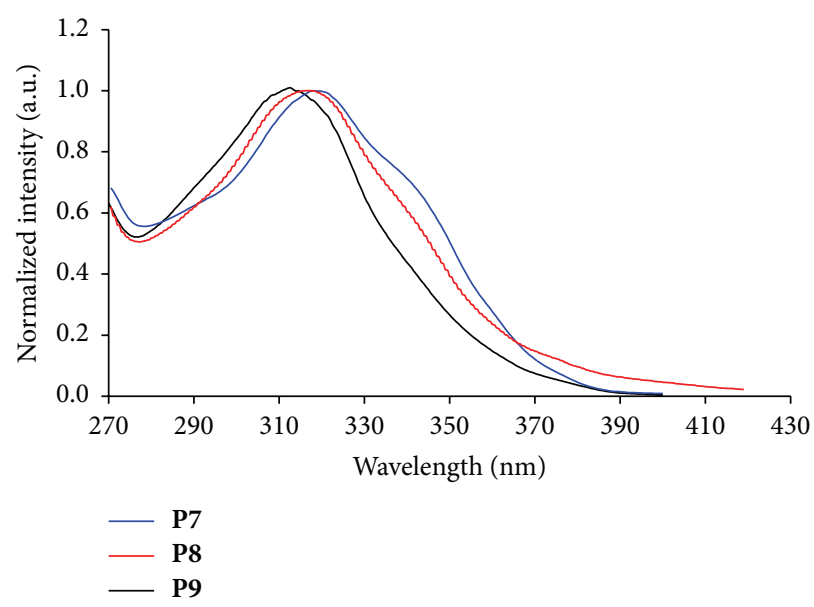

(c)

Figure 3: Electronic absorption spectra of (a) P1, P2, and P3; (b) P4, P5, and P6; and (c) P7, P8, and P9 recorded in DMF at $30^{\circ} \mathrm{C}$.

optical bandgap to the HOMO levels. Table 2 lists the values for the HOMO and LUMO levels. In the CV-experiments, the subsequent introduction of thiophene groups at the carbazole moieties in compounds P1 (CBP), P4, and P7 causes decreases in the HOMO levels of $-5.69,-5.70$, and $-5.72 \mathrm{eV}$, respectively. In the case of methyl substitution on the biphenyl ring in compounds P2, P5, and P8, the HOMO levels decrease to $-5.70,-5.89$, and $-5.85 \mathrm{eV}$, respectively, in comparison with P1, P4, and P7. However, by changing the biphenyl core to phenyl rings for compounds P3, P6, and P9, the HOMO levels are significantly affected $(-5.62,-5.94$, and $-5.99 \mathrm{eV}$, resp.).

The HOMO levels of $\mathbf{P 6}$ and $\mathbf{P 9}$ are the lowest amongst all the compounds, indicating that the introduction of thiophene and phenyl groups to the core leads to more stabilization of HOMO energy levels [52]. The order of the LUMO energies is P3 $>$ P2 > P1 > P4 > P7 > P5 > P6 > P8 > P9, indicating that compounds $\mathbf{P 8}$ and $\mathbf{P 9}$ possess greater electron-accepting abilities. A lower LUMO level suggests stronger intramolecular charge transfer interactions which result in a lower bandgap (Figure 6) [53].
$\Delta E$ values decrease significantly with the change of the bridging core group from biphenyl to dimethylbiphenyl or phenyl in P1-P3 and P7-P9, whereas $\Delta E$ values in $\mathbf{P 4 - P 6}$ increase in the presence of monothiophene at the 3-position of carbazole. The HOMO-LUMO gap of $\mathbf{P 9}$ is the narrowest among these nine compounds, which is expected to have the most outstanding photophysical properties. Therefore, the carbazole substituted with thiophene groups at the 3- and 6positions and phenyl as the core group leads to greater stabilization of HOMO and LUMO energy levels where the bandgap $(\Delta E)$ of all of the compounds is significantly reduced.

These considerations show that the energy levels of the CBP derivatives can be fine-tuned to some extent by varying the substitution pattern at the connecting biphenyl moiety as well as at the pendant carbazole. Particularly, the HOMO levels can be varied. Thus, through these slight variations in the molecular structure, the energy of the different layers in optoelectronic devices can be adjusted to minimize energy barriers within the devices [41]. $\pi$-Functional small molecules benefit from the fact that they are easy to purify, tend to possess high intrinsic carrier mobilities, and are able 


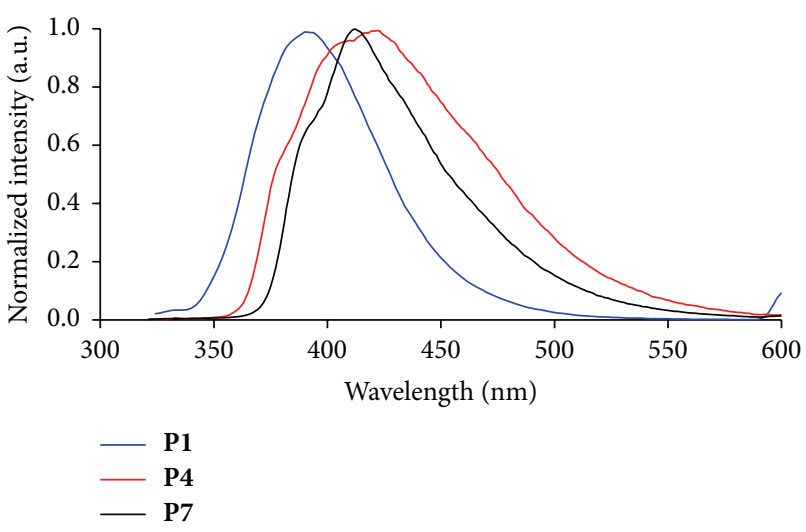

(a)

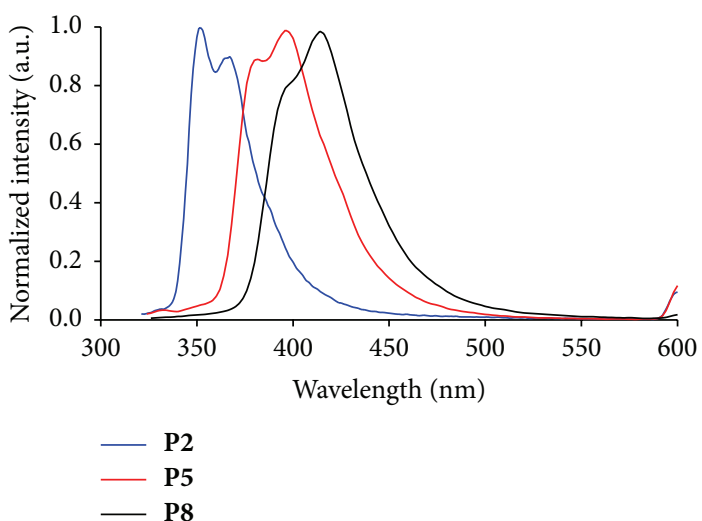

(b)

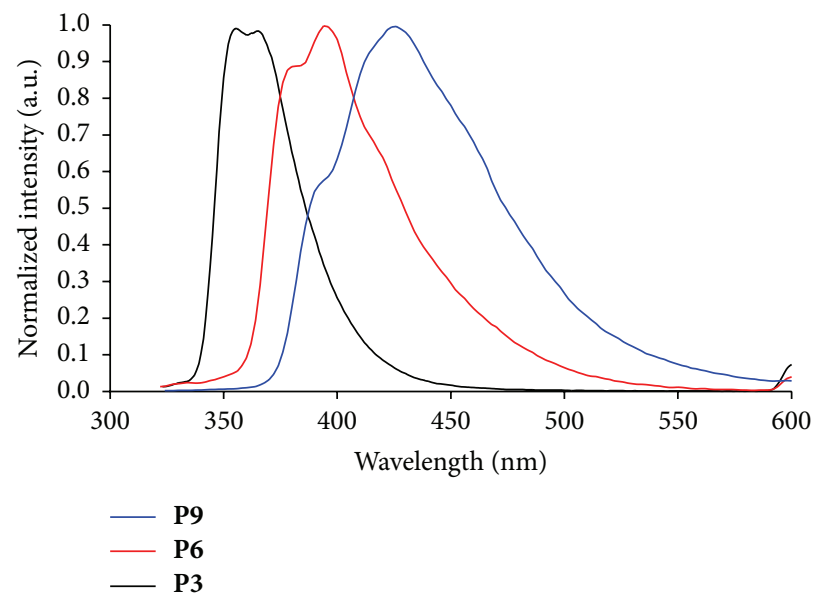

(c)

Figure 4: Emission spectra of (a) P1, P4, and P7; (b) P2, P5, and P8; and (c) P3, P6, and P9 recorded in DMF at $30^{\circ} \mathrm{C}$.

to self-assemble to achieve long-range order. An impressive library of thiophene oligomers has been built and explored over the past two decades [54, 55]. Symmetrical donoracceptor (DA) small molecules appended with solubilizing substituents and consisting of an electron-deficient core flanked with electron-rich groups are now being considered as alternatives to their all-donor counterparts [56].

2.4. Theoretical Approach. To obtain further insight into the electronic properties of $\mathbf{P 1 - P 9}$, geometrical optimization and frontier molecular orbital calculations were performed. All of the computations were performed using the GAUSSIAN 09W software package (Tables S1-S9 in Supplementary Material available online at http://dx.doi.org/10.1155/2016/9360230). The images presented in the figures were generated using ChemDraw and GaussView visualization programs. The geometries of the compounds in their ground state were optimized (Figure 6) employing the Density Functional Theory (DFT) method with restricted Becke's three parameter hybrid functional and the nonlocal Lee, Yang, and Parr gradientcorrected correlation functional B3LYP $[57,58]$ combined with the 6-31G functional basis set. This method has been found to be an accurate formalism for calculating the characteristic parameters of many molecular systems [59].
The contour plots of the HOMO and LUMO determined at the DFT/B3LYP/6-31G level for all of the compounds are shown in Figure 7. The HOMO is expected to lie on the electron-rich groups, affording an effective holetransporting property. The energy of the HOMO and LUMO orbitals is an important molecularly correlated parameter. The molecules with lower HOMO orbital energy levels have weaker electron-donating abilities. Moreover, the electronic density distribution in these orbitals permits prediction of the most probable sites of attack by reactive agents in the molecules investigated.

From the HOMO and LUMO orbitals shown in Figure 7, the HOMO is predominantly determined by the carbazole groups for P1-P3, whereas for P4-P7 the HOMO are mainly determined by the thiophene groups and their $\pi$ bonding orbitals, although the carbazoles also exert their influence; however, the LUMOs are predominantly localized on and primarily determined by the carbazole and biphenyl core groups and their $\pi^{*}$-bonding orbitals. Compounds P8 and P9 demonstrate an overlap between HOMO and LUMO on the acceptor carbazole group, which facilitates the charge transfer from the four electron-donating thiophene groups to the two electron-withdrawing carbazoles [53]. In addition to the stronger electron-donating ability 

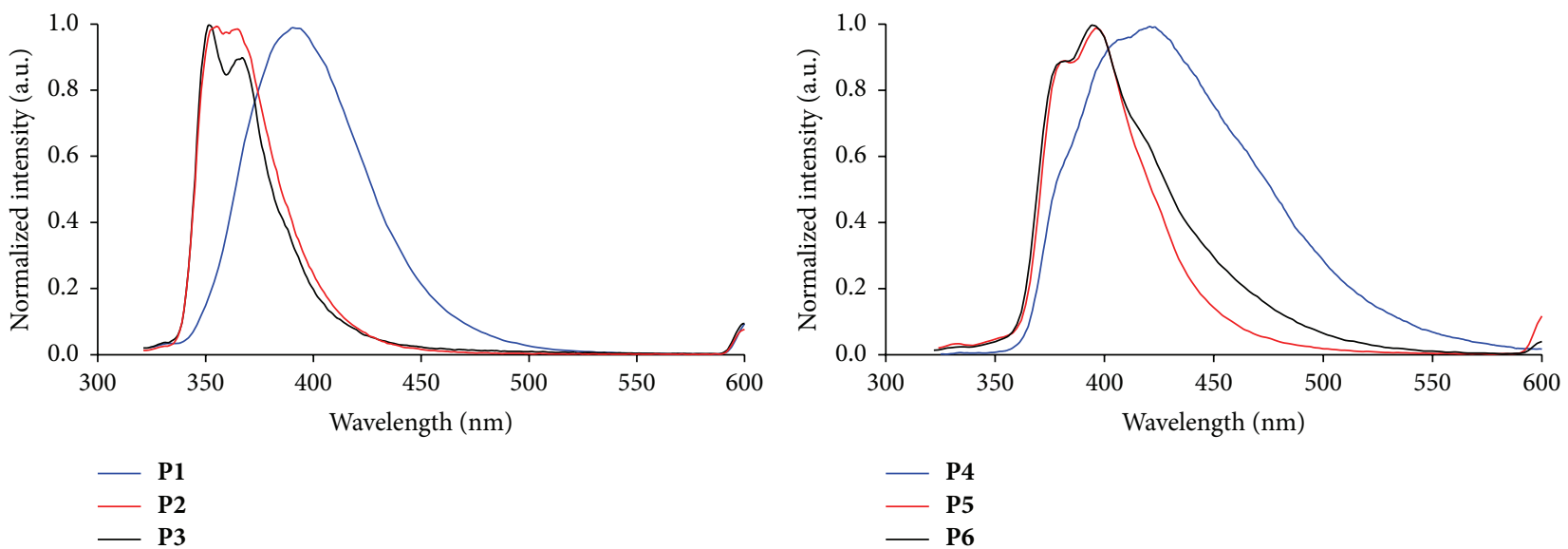

(a)

(b)

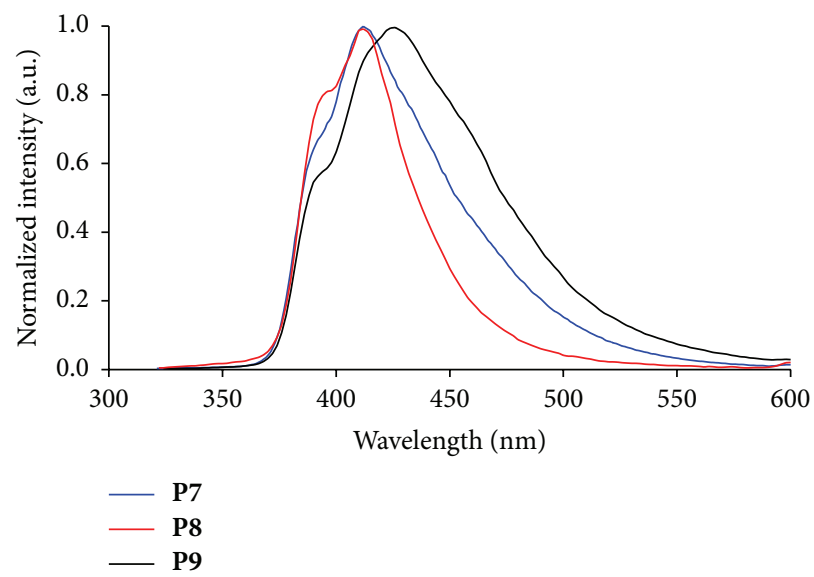

(c)

Figure 5: Emission spectra of (a) P1, P2, and P3; (b) P4, P5, and P6; and (c) P7, P8, and P9 recorded in DMF at $30^{\circ} \mathrm{C}$.

of the thiophene, compounds P7, P8, and P9 exhibit more planar structures and more effective $\pi$-conjugation, which result in strengthened intramolecular interactions and lower bandgaps. These results are consistent with the experimentally observed absorption properties of the resulting compound (Figure 3(c)). A clear difference between biphenyl and dimethylbiphenyl as core groups can be observed.

In fact, for $\mathrm{N}$-carbazole end-capped- $\pi$-conjugated molecules, the introduction of carbazole moieties at the terminal group of the conjugated backbone would result in a less planar molecule due to the planar character of carbazole groups. This fact is manifested by a perpendicular orientation to the backbone chain, which decreases the bond length between the core and the carbazole group. This decrease is attributed to the size and the electronegativity of the nitrogen atom. These large dihedral angles could minimize the degree of $\pi$-aggregation and thus improve the photoluminescence intensity [52]. Particularly, the 3,6-disubstituted structures present high dipole moments, indicating the presence of a significant charge transfer. This effect is more pronounced in the case of D-A structures (P4-P9) [52].

\section{Conclusion}

In conclusion, a series of carbazole-thiophene derivatives P4-P9 were prepared by means of Suzuki-Miyaura and Ullmann coupling reactions as key steps. The electronic structures were determined by UV-Vis, fluorescence spectral measurements, CV, and theoretical calculations. Based on this study, a clear picture about the effects of the structural variations of carbazole-thiophenes, the degree of conjugation, and the insertion of different core groups on their electronic and electrochemical properties emerges. The connection of carbazole-thiophene with a phenyl core and the addition of thiophene groups at the 3- and 6-positions resulted in a composite structure that exhibited a red shift in the emission spectrum. Carbazole connecting with more thiophenes and a phenyl core group leads to greater stabilization of the HOMO and LUMO energy levels where the bandgap $(\Delta E)$ of all of the compound-based-compounds is significantly reduced. The present study provides valuable information for the design and synthesis of new carbazole-thiophene-based systems. 


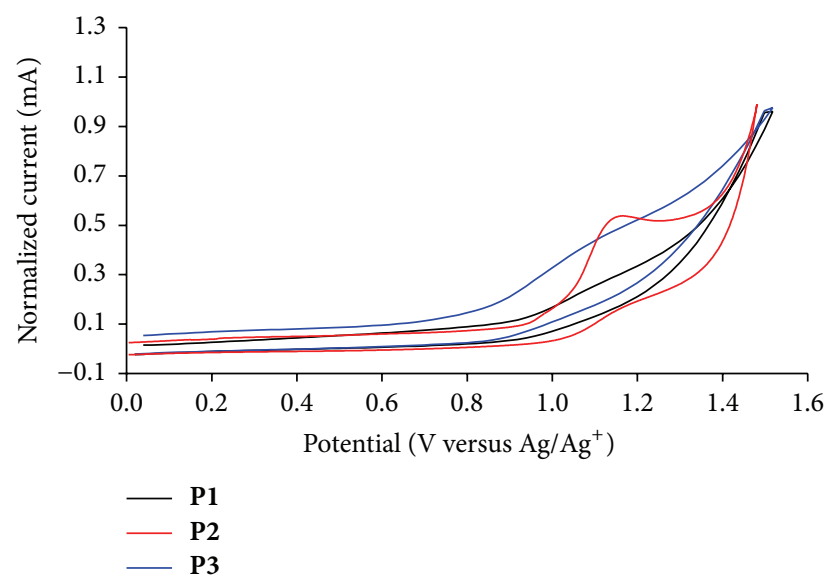

(a)

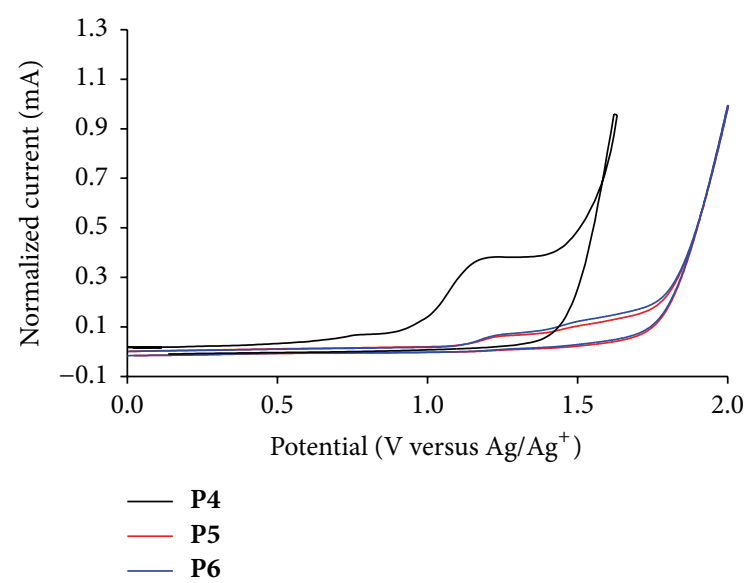

(b)

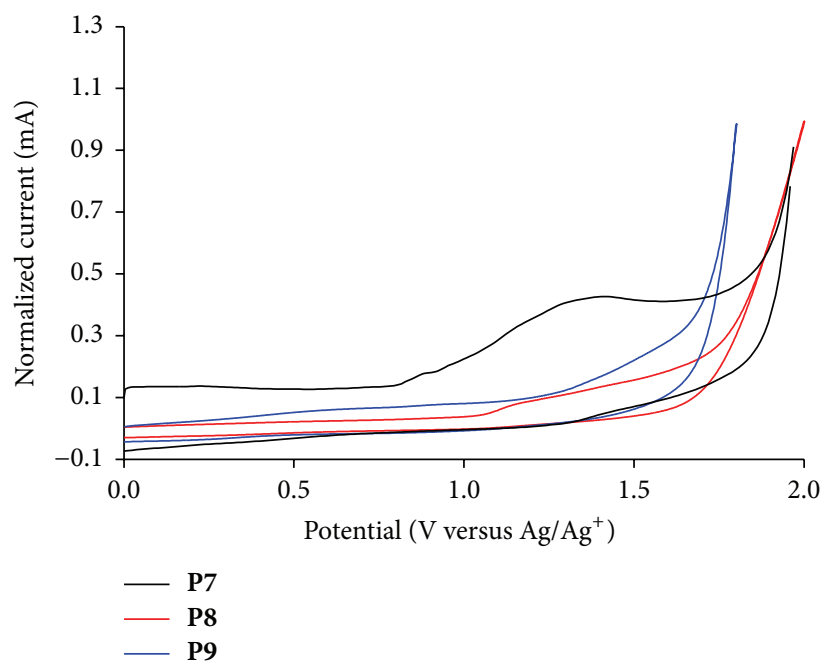

(c)

Figure 6: Cyclic voltammogram $\left(0.1 \mathrm{Vs}^{-1}\right)$ for (a) compounds P1, P2, and P3; (b) compounds P4, P5, and P6; and (c) compounds P7, P8, and $\mathbf{P 9}$ with ferrocene as an external standard in $\mathrm{DMF}-0.05 \mathrm{M}^{\mathrm{n}} \mathrm{Bu}_{4} \mathrm{NPF}_{6}$.

\section{Experimental Section}

4.1. General Information. All chemicals were commercially available and used as received unless otherwise specified. ${ }^{1} \mathrm{H}$ NMR (400 and $600 \mathrm{MHz}$ ) and ${ }^{13} \mathrm{C}$ NMR $(100 \mathrm{MHz})$ spectra were recorded using a spectrometer. Chemical shifts are reported in parts per million ( $\mathrm{ppm}$ ) relative to the residual solvent protons $\left({ }^{1} \mathrm{H}\right)$ or the solvent carbon $\left({ }^{13} \mathrm{C}\right)$ as internal standards. The mass spectra and high-resolution mass spectra (HRMS) were obtained using either electrospray ionization (ESI), atmospheric pressure chemical ionization (APCI) techniques, or MALDI-Tof. Absorption spectra were recorded on a UV-Vis spectrometer. Cyclic voltammetry (CV) was carried out using working electrode as glassy carbon, and counter electrode was platinum electrodes and $\mathrm{Ag} / \mathrm{Ag}^{+}\left(0.10 \mathrm{M} \mathrm{AgNO}_{3}\right.$ in DMF) as reference electrode. The electrochemical potential was calibrated against $\mathrm{Fc} / \mathrm{Fc}^{+}$. Theoretical Density Functional Theory (DFT) calculation was performed using GAUSSIAN 09W software package using the B3LYP method and 6-31G basis set.

\subsection{Synthesis of Compounds}

4.2.1. Preparation of Compound P1-P9. General procedure of Ullmann coupling procedure for preparation of carbazole-thiophene is as follows. A mixture of carbazole 1, 3-(thiophen-2-yl)carbazole 7 or 3,6-(dithiophene-2-yl)9Hcarbazole 9 (2 eq) and 4,4-diiodobiphenyl 2, 4,4-diiodo-2'2dimethyl-1,1-biphenyl 3 or 1,4-diiodobenzene 4 (1 eq) in 1,2dichlorobenzene $(10 \mathrm{~mL})$ was purged with nitrogen for 30 minutes. $\mathrm{K}_{2} \mathrm{CO}_{3}$ (1 eq), copper powder (2 eq), and 18-crown$6(20 \mathrm{~mol} \%)$ were added to the mixture and the resulting mixture was refluxed under nitrogen atmosphere for 3 days. The organic phase was filtered and the solvent removed under vacuo and purified with column chromatography (silica, ethyl acetate-hexane) to afford desired products.

4.2.2. Preparation of Compounds 7 and 9. General procedure for the Suzuki-Miyaura cross-coupling procedure for the preparation of carbazole-thiophene is as follows. A mixture of 3-iodocarbazole 5 or 3,6-diiodocarbazole 8 (1 eq) dissolved 

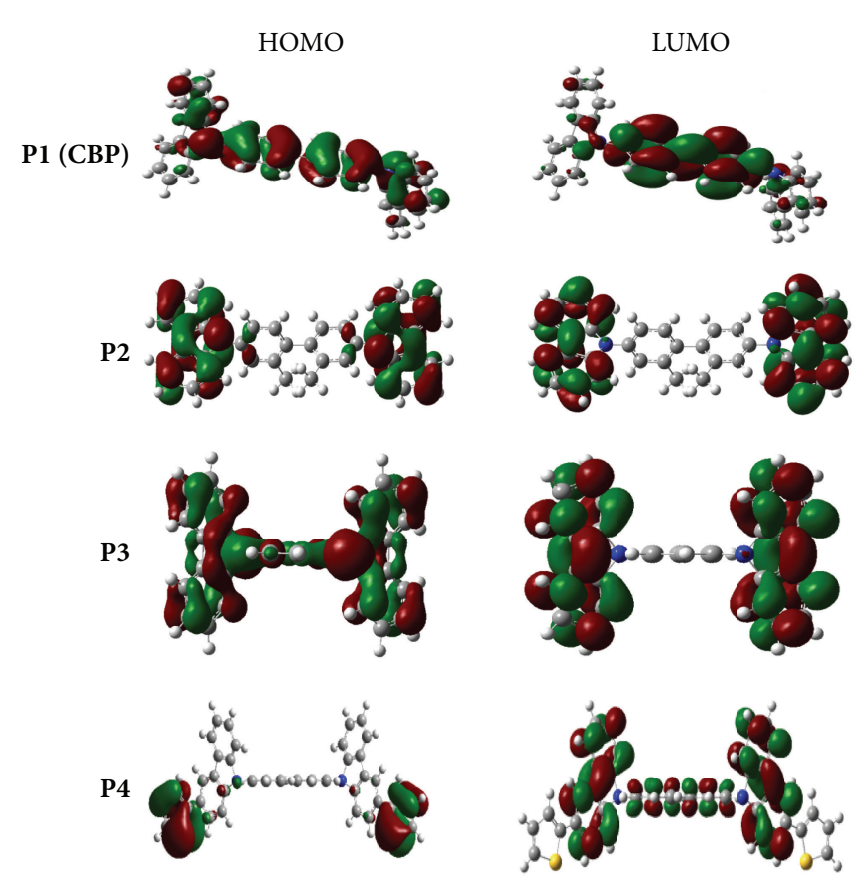

P5
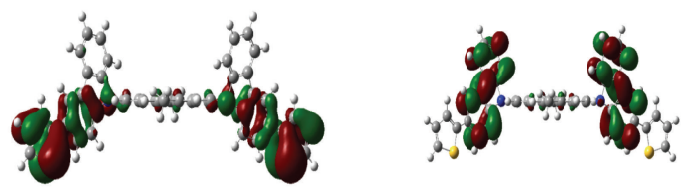

P6
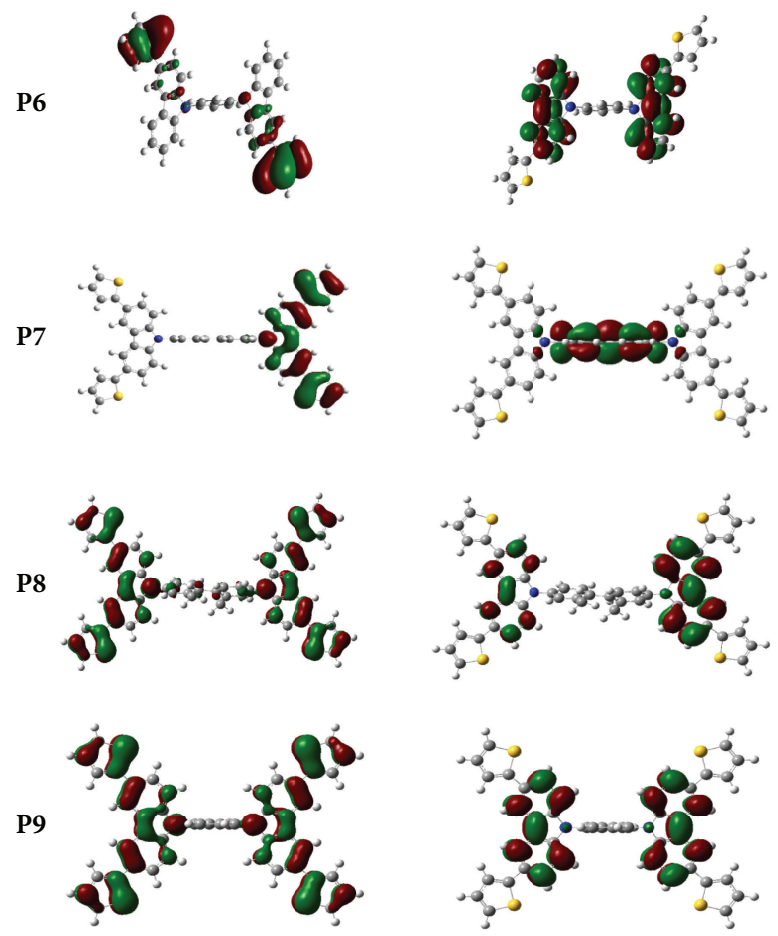

Figure 7: HOMO and LUMO frontier molecular orbitals of compounds P1-P9 that were calculated in vacuo at B3LYP/6-31G level of approximation. 
in $80 \mathrm{~mL}$ absolute ethanol was treated with a few drops of THF until the mixture completely dissolved and thiophene-2boronic acid pinacol ester $\mathbf{6}$ was added to the solution. $\mathrm{K}_{2} \mathrm{CO}_{3}$ (2 eq) in ethanol/water $(10: 1)$ was then added and purged with nitrogen for $30 \mathrm{~min} . \mathrm{Pd}\left(\mathrm{PPh}_{3}\right)_{4}$ (ca $0.5-1 \%$, per reaction point) was added to the mixture, and the resulting mixture was refluxed under a nitrogen atmosphere. The organic phase was separated, and the aqueous phase was extracted with dichloromethane. The combined organic phases were washed with water, dried over $\mathrm{Na}_{2} \mathrm{SO}_{4}$, and concentrated under reduce pressure. Recrystallization from hexane-dichloromethane afforded the desired product.

4.2.3. 4,4-Diiodobiphenyl (2) [60]. A mixture of biphenyl $4(4.62 \mathrm{~g}, 30 \mathrm{mmol})$, acetic acid $30 \mathrm{~mL}$, water $3 \mathrm{~mL}$, concentrated sulfuric acid $3 \mathrm{~mL}$, iodine $8.37 \mathrm{~g}$, periodic acid $(3.75 \mathrm{~g}, 16.5 \mathrm{mmol})$, and carbon tetrachloride $\left(\mathrm{CCl}_{4}, 4 \mathrm{~mL}\right)$ was stirred and maintained at $80^{\circ} \mathrm{C}$ for 4 hours. Afterwards, the slurry product was cooled to room temperature, poured into water, and extracted with dichloromethane. The combined dark purple organic layer was decolorized with sodium sulfite, dried with anhydrous sodium sulfate, filtered, and evaporated to dryness yielding $3.99 \mathrm{~g}$ of 2 pale yellow shiny powder (33\%): mp $200-202^{\circ} \mathrm{C}\left(\mathrm{mp}^{\text {lit. }} 200-201^{\circ} \mathrm{C}\right) .{ }^{1} \mathrm{H}$ NMR $\left(400 \mathrm{MHz}, \mathrm{CDCl}_{3}\right) \delta \mathrm{ppm} 7.78(\mathrm{~d}, J=8.56 \mathrm{~Hz}, 4 \mathrm{H}) 7.30$ $(\mathrm{d}, J=8.56 \mathrm{~Hz}, 4 \mathrm{H}) ;{ }^{13} \mathrm{C}$ NMR $\left(100 \mathrm{MHz}, \mathrm{CDCl}_{3}\right) \delta$ 139.6, 137.7, 128.7, 93.5. HR-ESI-MS: $m / z$ calcd for $[M+$ $\mathrm{H}]^{+}=\mathrm{C}_{12} \mathrm{H}_{8} \mathrm{I}_{2}$ 406.8795; found 406.8793. Anal. calcd. for $\mathrm{C}_{12} \mathrm{H}_{8} \mathrm{I}_{2}$ : C, 35.50; H, 1.99; I, 62.51. Found: C, 35.45; H, 1.80; I, 62.43 .

4.2.4. 4,4'-Di(9H-carbazol-9-yl)-1,1'-biphenyl (P1) [41]. The title compound was prepared from 2 eq carbazole $1(0.09 \mathrm{~g}$, $0.50 \mathrm{mmol})$ and 1 eq 4,4-diiodobiphenyl $2(0.10 \mathrm{~g}, 0.25 \mathrm{mmol})$ as white shiny powder P1 (0.07 g, 50\%). Mp 283. ${ }^{1} \mathrm{H}$ NMR $\left(400 \mathrm{MHz}, \mathrm{CDCl}_{3}\right) \delta \mathrm{ppm} 8.21(\mathrm{~d}, J=7.70 \mathrm{~Hz}, 4 \mathrm{H}), 7.95$ $(\mathrm{d}, J=8.44 \mathrm{~Hz}, 4 \mathrm{H}), 7.74(\mathrm{~d}, J=8.56 \mathrm{~Hz}, 4 \mathrm{H}), 7.55(\mathrm{~d}$, $J=7.90 \mathrm{~Hz}, 4 \mathrm{H}), 7.48(\mathrm{td}, J=7.10,1.00 \mathrm{~Hz}, 4 \mathrm{H}), 7.35(\mathrm{td}$, $J=6.80,1.00 \mathrm{~Hz}, 4 \mathrm{H}) ;{ }^{13} \mathrm{C} \mathrm{NMR}\left(100 \mathrm{MHz}, \mathrm{CDCl}_{3}\right) \delta \mathrm{ppm}$ $140.8,139.3,137.3,128.5,127.5,126.0,123.5,120.4,120.1,109.8$. HR-ESI-MS: $m / z$ calcd for $[\mathrm{M}+\mathrm{H}]^{+}=\mathrm{C}_{36} \mathrm{H}_{24} \mathrm{~N}_{2}$ 485.2017; found 485.2015. Anal. calcd. for $\mathrm{C}_{36} \mathrm{H}_{24} \mathrm{~N}_{2}$ : C, 89.23; H, 4.99; N, 5.78. Found: C, 89.20; H, 4.80; N, 5.72.

4.2.5. 9,9'-(2,2' -Dimethyl-[1,1'-biphenyl]-4,4'-diyl)bis( $9 H$-carbazole) (P2) [41]. The title compound was prepared from 2.2 eq of carbazole $1(0.17 \mathrm{~g}, 0.05 \mathrm{mmol})$ and 1 eq of 4,4 diiodo-2' 2-dimethyl-1,1-biphenyl 3 (0.10 g, $0.02 \mathrm{mmol}$ ). Purification by column chromatography (silica, dichloromethane-hexane) gave $\mathbf{P 2}$ as a white powder $(0.01 \mathrm{~g}, 60 \%) .{ }^{1} \mathrm{H}$ NMR $\left(400 \mathrm{MHz}, \mathrm{CDCl}_{3}\right) \delta \mathrm{ppm} 8.21(\mathrm{~d}, J=7.70 \mathrm{~Hz}, 4 \mathrm{H})$, 7.55-7.60 (m, $6 \mathrm{H}), 7.45-7.55(\mathrm{~m}, 8 \mathrm{H}), 7.35(\mathrm{td}, J=7.40$, $0.98 \mathrm{~Hz}, 4 \mathrm{H}), 2.32(\mathrm{~s}, 6 \mathrm{H}) .{ }^{13} \mathrm{C}$ NMR $\left(100 \mathrm{MHz}, \mathrm{CDCl}_{3}\right)$ $\delta \mathrm{ppm} 140.9,140.0,137.9,136.9,130.8,128.3,125.9,124.3,123.4$, 120.3, 119.9, 109.9, 20.13. HR-ESI-MS: $\mathrm{m} / z$ calcd for $[\mathrm{M}+$ $\mathrm{H}]^{+}=\mathrm{C}_{38} \mathrm{H}_{28} \mathrm{~N}_{2}$ 513.2330; found 513.2332. Anal. calcd. for $\mathrm{C}_{38} \mathrm{H}_{28} \mathrm{~N}_{2}$ : C, 89.03; H, 5.50; N, 5.46. Found: C, 89.00; H, 5.45; N, 5.43 .
4.2.6. 1,4-Di(9H-carbazol-9-yl)benzene (P3). The title compound was prepared from 2 eq of carbazole $1(0.08 \mathrm{~g}$, $0.50 \mathrm{mmol})$ and $1 \mathrm{eq}$ of 1,4-diiodobenzene 4 ( $0.10 \mathrm{~g}$, $0.23 \mathrm{mmol}$ ). Purification by column chromatography (silica, dichloromethane-hexane) gave $\mathbf{P 3}$ as a white solid (0.08 g, 80\%). Mp $323^{\circ} \mathrm{C} .{ }^{1} \mathrm{H} \mathrm{NMR}\left(400 \mathrm{MHz}, \mathrm{CDCl}_{3}\right) \delta \mathrm{ppm}$ $8.22(\mathrm{~d}, J=7.58 \mathrm{~Hz}, 4 \mathrm{H}), 7.85(\mathrm{~s}, 4 \mathrm{H}), 7.60(\mathrm{~d}, J=8.20 \mathrm{~Hz}, 4$ $\mathrm{H}), 7.51(\mathrm{td}, J=7.67,1.16 \mathrm{~Hz}, 4 \mathrm{H}), 7.37(\mathrm{td}, J=7.40,0.98 \mathrm{~Hz}$, $4 \mathrm{H}) .{ }^{13} \mathrm{C}$ NMR $\left(100 \mathrm{MHz}, \mathrm{CDCl}_{3}\right) \delta \mathrm{ppm} \mathrm{140.8,} \mathrm{136.9,} \mathrm{128.4,}$ 126.1, 123.6, 120.4, 120.3, 109.7. HR-ESI-MS: $\mathrm{m} / z$ calcd for $[\mathrm{M}$ $+\mathrm{H}]^{+}=\mathrm{C}_{30} \mathrm{H}_{20} \mathrm{~N}_{2}$ 409.1704; found 409.1706. Anal. calcd. for $\mathrm{C}_{30} \mathrm{H}_{20} \mathrm{~N}_{2}$ : C, 88.21; $\mathrm{H}, 4.93 ; \mathrm{N}, 6.86$. Found: C, 88.18; H, $4.90 ; \mathrm{N}, 6.79$.

4.2.7. 3-Iodocarbazole (5) [61]. Carbazole 1 (16.7 g, $101 \mathrm{mmol})$ was dissolved in boiling glacial acetic acid $(250 \mathrm{~mL})$, and KI (11.73 g, $135 \mathrm{mmol})$ was added. The solution was cooled, ground potassium iodate $(23.42 \mathrm{~g}, 150 \mathrm{mmol})$ was added, and the mixture was boiled until it acquired a clear strawcolored tint $(10 \mathrm{~min})$. The hot solution was decanted from the undissolved potassium iodate, and it was allowed to cool to $45^{\circ} \mathrm{C}$. The faintly brown plates were rapidly filtered off and recrystallized from alcohol, and the solution was allowed to cool to $45^{\circ} \mathrm{C}$. The faintly brown plates were rapidly filtered off and recrystallized from ethanol; the solution was allowed to cool to $45^{\circ} \mathrm{C}$ and filtered, yielding $9.73 \mathrm{~g}(47 \%)$ of 5 as a brown solid; mp $202^{\circ} \mathrm{C}\left(\mathrm{mp}^{\text {lit. }} 202^{\circ} \mathrm{C}\right),{ }^{1} \mathrm{H}$ NMR $\left(600 \mathrm{MHz}, \mathrm{CDCl}_{3}\right.$ ) $\delta$ ppm 8.41 (s, $1 \mathrm{H}), 8.11$ (br. s., $1 \mathrm{H}), 8.04(\mathrm{~d}, J=7.70 \mathrm{~Hz}$, $1 \mathrm{H}), 7.68(\mathrm{dd}, J=8.53,1.74 \mathrm{~Hz}, 1 \mathrm{H}), 7.42-7.49(\mathrm{~m}, 2 \mathrm{H})$, 7.22-7.28 (m, $2 \mathrm{H}) ;{ }^{13} \mathrm{C}$ NMR $\left(100 \mathrm{MHz}, \mathrm{CDCl}_{3}\right) \delta \mathrm{ppm} 139.5$, $138.6,134.1,129.2,126.6,125.9,122.1,120.5,119.9,112.6,110.7$. Maldi-Tof MS: $m / z$ calcd for $\left[\mathrm{M}^{+}\right]=\mathrm{C}_{12} \mathrm{H}_{8} \mathrm{IN} 292.970$; found 292.971. Anal. calcd. for $\mathrm{C}_{12} \mathrm{H}_{8} \mathrm{IN}$ : C, 49.17; H, 2.75; I, 43.30; N, 4.78. Found: C, 49.10; H, 2.71; I, 43.25; N, 4.73.

4.2.8. 3-(Thiophen-2-yl)carbazole (7) [62]. The title product was prepared from 3-iodocarbazole $5(2.4 \mathrm{~g}, 8.0 \mathrm{mmol})$ as an off-white solid $(1.60 \mathrm{~g}, 80 \%) \mathrm{mp} 196^{\circ} \mathrm{C}$; $\mathrm{mp}^{\text {lit. }} 197^{\circ} \mathrm{C} .{ }^{1} \mathrm{H}$ NMR $\left(600 \mathrm{MHz}, \mathrm{CDCl}_{3}\right) \delta \mathrm{ppm} 8.32(\mathrm{~s}, 1 \mathrm{H}), 8.14(\mathrm{~d}, J=7.79 \mathrm{~Hz}, 1$ H), 8.10 (br. s., $1 \mathrm{H}), 7.72(\mathrm{~d}, J=8.34 \mathrm{~Hz}, 1 \mathrm{H}), 7.42-7.50$ (m, $4 \mathrm{H}), 7.37(\mathrm{~d}, J=3.48 \mathrm{~Hz}, 1 \mathrm{H}), 7.29-7.33(\mathrm{~m}, 1 \mathrm{H}), 7.13$ (ddd, $J=5.02,3.55,1.42 \mathrm{~Hz}, 1 \mathrm{H}) ;{ }^{13} \mathrm{C} \mathrm{NMR}\left(100 \mathrm{MHz}, \mathrm{CDCl}_{3}\right) \delta$ 145.7, 140.0, 139.0, 128.0, 126.4, 126.2, 124.6, 123.8, 123.7, 123.3, $122.2,120.5,119.7,117.9,110.9,110.8$; HR-ESI-MS $m / z$ calcd for $[\mathrm{M}+\mathrm{H}]^{+}=\mathrm{C}_{16} \mathrm{H}_{11} \mathrm{NS} 250.0692$, found 250.0690. Anal. calcd. for $\mathrm{C}_{16} \mathrm{H}_{11} \mathrm{NS}$ : C, 77.11; $\mathrm{H}, 4.45 ; \mathrm{N}, 5.62 ; \mathrm{S}, 12.83$. Found: $\mathrm{C}$, $77.08 ; \mathrm{H}, 4.40 ; \mathrm{N}, 5.58 ; \mathrm{S}, 12.79$.

4.2.9. Preparation of $\boldsymbol{P 4}$. The compound was prepared from 2 eq of 3-(thiophene-2-yl)-9H-carbazole 7 (0.3241g, $1.3 \mathrm{mmol})$ and 1 eq of 4,4-diiodobiphenyl $2(0.25 \mathrm{~g}, 0.6 \mathrm{mmol})$ as an off-white solid $(0.1 \mathrm{~g}, 26 \%) .{ }^{1} \mathrm{H} \mathrm{NMR}\left(400 \mathrm{MHz}, \mathrm{CDCl}_{3}\right)$ $\delta \mathrm{ppm} 8.41(\mathrm{~s}, 2 \mathrm{H}), 8.24(\mathrm{~d}, J=8.31 \mathrm{~Hz}, 2 \mathrm{H}), 7.97(\mathrm{~d}$, $J=8.07 \mathrm{~Hz}, 4 \mathrm{H}), 7.75(\mathrm{dd}, J=8.62,3.12 \mathrm{~Hz}, 6 \mathrm{H}), 7.50-7.58$ (m, $5 \mathrm{H}), 7.33-7.43(\mathrm{~m}, 5 \mathrm{H}), 7.31(\mathrm{~d}, J=4.77 \mathrm{~Hz}, 2 \mathrm{H}), 7.15(\mathrm{t}$, $J=4.20 \mathrm{~Hz}, 2 \mathrm{H}) ;{ }^{13} \mathrm{C} \mathrm{NMR}\left(100 \mathrm{MHz}, \mathrm{CDCl}_{3}\right) \delta \mathrm{ppm} \mathrm{145.6}$, $141.4,140.4,140.1,138.0,136.7,130.8,128.3,128.0,126.8,126.3$, $124.6,124.2,123.9,123.3,122.3,120.5,120.2,117.9,110.3,110.1$. 
HR-ESI-MS: $m / z$ calcd for $[\mathrm{M}+\mathrm{H}]^{+}=\mathrm{C}_{44} \mathrm{H}_{28} \mathrm{~N}_{2} \mathrm{~S}_{2} 649.1772$; found 649.1775. Anal. calcd. for $\mathrm{C}_{44} \mathrm{H}_{28} \mathrm{~N}_{2} \mathrm{~S}_{2}$ : C, 81.47; $\mathrm{H}, 4.35$; N, 4.32; S, 9.86. Found: C, 81.45; H, 4.32; N, 4.28; S, 9.82.

4.2.10. Preparation of $\boldsymbol{P 5}$. The compound was prepared from $2 \mathrm{eq}$ of 3-(thiophene-2-yl)-9H-carbazole 7 (0.12 g, $0.48 \mathrm{mmol}$ ) and 1 eq of 4,4-diiodo-2' 2 -dimethyl-1,1-biphenyl $3(0.10 \mathrm{~g}, 0.23 \mathrm{mmol})$ as a pale yellow solid $(0.05 \mathrm{~g}, 35 \%) .{ }^{1} \mathrm{H}$ $\operatorname{NMR}\left(400 \mathrm{MHz}, \mathrm{CDCl}_{3}\right) \delta \mathrm{ppm} 8.42(\mathrm{~s}, 2 \mathrm{H}), 8.24(\mathrm{~d}, J=$ $7.46 \mathrm{~Hz}, 2 \mathrm{H}), 7.75(\mathrm{~d}, J=8.56 \mathrm{~Hz}, 2 \mathrm{H}), 7.46-7.60(\mathrm{~m}, 12 \mathrm{H})$, $7.41(\mathrm{dd}, J=3.55,1.10 \mathrm{~Hz}, 2 \mathrm{H}), 7.36(\mathrm{td}, J=7.43,0.92 \mathrm{~Hz}, 2$ H), 7.31 (dd, $J=5.14,1.10 \mathrm{~Hz}, 2 \mathrm{H}), 7.16(\mathrm{dd}, J=5.14,3.55 \mathrm{~Hz}$, $2 \mathrm{H}), 2.33$ (s, $6 \mathrm{H}) ;{ }^{13} \mathrm{C} \mathrm{NMR}\left(100 \mathrm{MHz}, \mathrm{CDCl}_{3}\right) \delta \mathrm{ppm} \mathrm{145.6}$, $141.4,140.4,140.1,138.0,136.7,130.8,128.3,128.0,126.8,126.3$, $124.6,124.2,123.9,123.3,122.3,120.5,120.2,117.9,110.3,110.1$, 20.2. HR-ESI-MS: $m / z$ calcd for $[\mathrm{M}+\mathrm{H}]^{+}=\mathrm{C}_{46} \mathrm{H}_{32} \mathrm{~N}_{2} \mathrm{~S}_{2}$ 677.2085; found 677.2080. Anal. calcd. for $\mathrm{C}_{46} \mathrm{H}_{32} \mathrm{~N}_{2} \mathrm{~S}_{2}$ : C, 81.65; H, 4.77; N, 4.14; S, 9.45. Found: C, 81.62; H, 4.74; N, 4.10; S, 9.41 .

4.2.11. Preparation of P6. The compound was prepared from 2 eq of 3-(thiophene-2-yl)-9H-carbazole 7 (0.16 g, $0.60 \mathrm{mmol})$ and $1 \mathrm{eq}$ of 1,4 -diiodobenzene $4(0.10 \mathrm{~g}$, $0.30 \mathrm{mmol}$ ). Purification by column chromatography (silica, chloroform-hexane) gave $\mathbf{P 6}$ as a pale yellow solid $(0.08 \mathrm{~g}$, $48 \%) .{ }^{1} \mathrm{H}$ NMR (600 MHz, $\mathrm{CDCl}_{3}$ ) $\delta$ ppm 8.42 (s, $\left.2 \mathrm{H}\right), 8.25$ $(\mathrm{d}, J=7.52 \mathrm{~Hz}, 2 \mathrm{H}), 7.87(\mathrm{~s}, 4 \mathrm{H}), 7.77(\mathrm{dd}, J=8.53,1.74 \mathrm{~Hz}$, $2 \mathrm{H}), 7.60(\mathrm{t}, J=8.60 \mathrm{~Hz}, 4 \mathrm{H}), 7.52(\mathrm{td}, J=7.50,1.00 \mathrm{~Hz}, 2$ $\mathrm{H}), 7.42(\mathrm{dd}, J=3.48,1.10 \mathrm{~Hz}, 2 \mathrm{H}), 7.39(\mathrm{t}, J=6.97 \mathrm{~Hz}, 2 \mathrm{H})$, $7.32(\mathrm{dd}, J=5.04,1.01 \mathrm{~Hz}, 2 \mathrm{H}), 7.16(\mathrm{dd}, J=5.14,3.48 \mathrm{~Hz}$, $2 \mathrm{H}) ;{ }^{13} \mathrm{C}$ NMR $\left(100 \mathrm{MHz}, \mathrm{CDCl}_{3}\right) \delta \mathrm{ppm} \mathrm{128.3,} \mathrm{128.1,} \mathrm{127.2,}$ 126.5, 124.8, 124.1, 124.0, 123.5, 122.4 , 120.6, 120.6, 118.0, 110.1, 109.9. HR-ESI-MS: $m / z$ calcd for $[\mathrm{M}+\mathrm{H}]^{+}=\mathrm{C}_{38} \mathrm{H}_{24} \mathrm{~N}_{2} \mathrm{~S}_{2}$ 573.1459; found 573.1484. Anal. calcd. for $\mathrm{C}_{38} \mathrm{H}_{24} \mathrm{~N}_{2} \mathrm{~S}_{2}$ : C, 79.72; H, 4.22; N, 4.89; S, 11.17. Found: C, 79.69; H, 4.20; N, 4.86; S, 11.13 .

4.2.12. 3,6-Diiodocarbazole (8) [61]. Carbazole 1 (12.23 g, $73 \mathrm{mmol})$ was dissolved in boiling glacial acetic acid $(300 \mathrm{~mL})$, and KI (15.84 g, $95 \mathrm{mmol})$ was added. The solution was cooled, ground potassium iodate $(23.42 \mathrm{~g}, 150 \mathrm{mmol})$ was added, and the mixture was then boiled until it acquired a clear straw-colored tint $(10 \mathrm{~min})$. The hot solution was decanted from the undissolved potassium iodate, and it was allowed to cool to $45^{\circ} \mathrm{C}$. The faintly brown plates were rapidly filtered off and recrystallized from alcohol, and the solution was allowed to cool to $45^{\circ} \mathrm{C}$ and filtered, yielding $5.75 \mathrm{~g}$ of $\mathbf{8}$

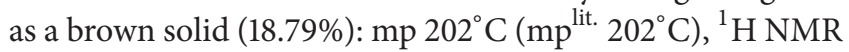
$\left(400 \mathrm{MHz} \mathrm{CDCl}_{3}\right) \delta$ ppm 8.34 (s, $\left.2 \mathrm{H}\right), 8.16$ (br. s., $\left.1 \mathrm{H}\right), 7.70$ $(\mathrm{dd}, J=8.53,1.63 \mathrm{~Hz}, 2 \mathrm{H}), 7.23(\mathrm{~d}, J=8.41 \mathrm{~Hz}, 2 \mathrm{H}) ;{ }^{13} \mathrm{C}$ NMR $\left(100 \mathrm{MHz}, \mathrm{CDCl}_{3}\right) \delta 138.5,134.8,129.4,124.5,112.7$ and 82.5. Maldi-Tof MS: $m / z$ calcd for $\left[\mathrm{M}^{+}\right]=\mathrm{C}_{12} \mathrm{H}_{7} \mathrm{I}_{2} \mathrm{~N} 418.867$; found 418.868. Anal. calcd. for $\mathrm{C}_{12} \mathrm{H}_{7} \mathrm{I}_{2} \mathrm{~N}$ : C, 34.40; H, 1.68; I, 60.58; N, 3.34. Found: C, 34.38; H, 1.65; I, 60.55; N, 3.30.

4.2.13. 3,6-Di(thiophen-2-yl)-9H-carbazole (9). The compound was prepared from 3,6-diiodocarbazole 8 as a white solid (0.70 g, 59\%): mp $127^{\circ} \mathrm{C} .{ }^{1} \mathrm{H} \mathrm{NMR}\left(600 \mathrm{MHz}, \mathrm{CDCl}_{3}\right.$ ) $\delta$ ppm 8.35 (s, $2 \mathrm{H}$ ), 8.13 (br. s., $1 \mathrm{H}$ ), 7.73 (dd, $J=8.39,1.70 \mathrm{~Hz}$, $2 \mathrm{H}), 7.44(\mathrm{~d}, J=8.53 \mathrm{~Hz}, 2 \mathrm{H}), 7.38(\mathrm{~d}, J=3.48 \mathrm{~Hz}, 2 \mathrm{H})$, $7.30(\mathrm{~d}, J=5.04 \mathrm{~Hz}, 2 \mathrm{H}), 7.23(\mathrm{dd}, J=10.36,8.53 \mathrm{~Hz}, 1$ $\mathrm{H}), 7.12-7.16$ (m, $2 \mathrm{H}) ;{ }^{13} \mathrm{C}$ NMR $\left(100 \mathrm{MHz}, \mathrm{CDCl}_{3}\right) \delta 145.5$, 139.4, 128.0, 126.7, 124.9, 123.9, 123.8, 122.3, 118.0, 111.1. HR-ESIMS $m / z$ calcd for $[\mathrm{M}+\mathrm{H}]^{+}=\mathrm{C}_{20} \mathrm{H}_{13} \mathrm{NS}_{2}$ 332.0569; found 332.0569. Anal. calcd. for $\mathrm{C}_{20} \mathrm{H}_{13} \mathrm{NS}_{2}$ : C, 72.52; $\mathrm{H}, 3.95 ; \mathrm{N}$, 4.23; S, 19.30. Found: C, 72.49; H, 3.91; N, 4.19; S, 19.27.

4.2.14. Preparation of $\boldsymbol{P} 7$. The compound was prepared from 2 eq of 3,6-di(thiophen-2-yl)-9H-carbazole 9 (0.43 g, $1.30 \mathrm{mmol})$ and $1 \mathrm{eq}$ of 4,4-diiodobiphenyl 2 (0.25 g, $0.60 \mathrm{mmol})$. Recrystallization from absolute ethanol gave P7 as a pale yellow solid (1.0 g, 75\%). ${ }^{1} \mathrm{H} \mathrm{NMR}(600 \mathrm{MHz}$, $\left.\mathrm{CDCl}_{3}\right) \delta \mathrm{ppm} 8.44(\mathrm{~s}, 4 \mathrm{H}), 7.98(\mathrm{~d}, J=8.44 \mathrm{~Hz}, 3 \mathrm{H}), 7.76$ $(\mathrm{d}, J=8.07 \mathrm{~Hz}, 8 \mathrm{H}), 7.53(\mathrm{~d}, J=8.44 \mathrm{~Hz}, 4 \mathrm{H}), 7.43(\mathrm{dd}$, $J=3.48,1.10 \mathrm{~Hz}, 4 \mathrm{H}), 7.32(\mathrm{dd}, J=5.13,0.92 \mathrm{~Hz}, 4 \mathrm{H}), 7.16$ $(\mathrm{dd}, J=4.95,3.48 \mathrm{~Hz}, 5 \mathrm{H}) ;{ }^{13} \mathrm{C} \mathrm{NMR}\left(100 \mathrm{MHz}, \mathrm{CDCl}_{3}\right)$ $\delta$ ppm 145.3, 140.8, 139.4, 137.0, 128.7, 128.1, 127.3, 127.3, 125.0, 124.0, 123.9, 122.5, 118.0, 110.4. Mp $268^{\circ} \mathrm{C}$. HR-APCI-MS: $m / z$ calcd for $[\mathrm{M}+\mathrm{H}]^{+}=\mathrm{C}_{52} \mathrm{H}_{32} \mathrm{~N}_{2} \mathrm{~S}_{4}$ 813.1526; found 813.1522. Anal. calcd. for $\mathrm{C}_{52} \mathrm{H}_{32} \mathrm{~N}_{2} \mathrm{~S}_{4}$ : C, 76.85; H, 3.97; N, 3.45; S, 15.74. Found: C, 76.82; H, 3.95; N, 3.41; S, 15.70.

4.2.15. Preparation of $\boldsymbol{P 8}$. The compound was prepared from 2.2 eq of 3,6-di(thiophen-2-yl)-9H-carbazole 9 (0.17 g, $0.05 \mathrm{mmol})$ and 1 eq of 4,4-diiodo-2' 2-dimethyl-1,1-biphenyl $3(0.10 \mathrm{~g}, 0.02 \mathrm{mmol})$. Purification by column chromatography (silica, dichloromethane-hexane) gave $\mathbf{P 8}$ as a white solid (0.01 g, 60\%). ${ }^{1} \mathrm{H}$ NMR $\left(400 \mathrm{MHz}, \mathrm{CDCl}_{3}\right) \delta \mathrm{ppm} 8.45$ (s, 4 $\mathrm{H}), 7.69-7.83(\mathrm{~m}, 6 \mathrm{H}), 7.49-7.63(\mathrm{~m}, 6 \mathrm{H}), 7.37-7.49(\mathrm{~m}, 6 \mathrm{H})$, 7.29-7.35 (m, $4 \mathrm{H}), 7.11-7.19$ (m, $4 \mathrm{H}), 1.28$ (s, $6 \mathrm{H}) .{ }^{13} \mathrm{C} \mathrm{NMR}$ $\left(100 \mathrm{MHz}, \mathrm{CDCl}_{3}\right) \delta \mathrm{ppm} 145.6,145.4,142.1,141.8,140.9,128.1$, 124.9, 124.2, 124.0, 123.9, 123.6, 122.4, 122.3, 118.0, 111.4, 110.4, 20.2. HR-ESI-MS: $m / z$ calcd for $[\mathrm{M}+\mathrm{H}]^{+}=\mathrm{C}_{54} \mathrm{H}_{36} \mathrm{~N}_{2} \mathrm{~S}_{4}$ 841.1841; found 841.1842. Anal. calcd. for $\mathrm{C}_{54} \mathrm{H}_{36} \mathrm{~N}_{2} \mathrm{~S}_{4}$ : C, 77.14; H, 4.32; N, 3.33; S, 15.21. Found: C, 77.12; H, 4.30; N, 3.29; S, 15.18 .

4.2.16. Preparation of $\boldsymbol{P 9}$. The compound was prepared from $2 \mathrm{eq}$ of 3,6-di(thiophen-2-yl)-9H-carbazole 9 (0.21 g, $0.60 \mathrm{mmol})$ and $1 \mathrm{eq}$ of 1,4-diiodobenzene 4 (0.10 g, $0.30 \mathrm{mmol}$ ). Purification by column chromatography (silica, chloroform-hexane) gave $\mathbf{P 9}$ as a pale yellow solid $(0.1 \mathrm{~g}$, $50 \%) .{ }^{1} \mathrm{H}$ NMR (400 MHz, $\mathrm{CDCl}_{3}$ ) $\delta$ ppm 8.46 (s, $4 \mathrm{H}$ ), 7.90 $(\mathrm{s}, 4 \mathrm{H}), 7.79(\mathrm{dd}, J=8.50,1.65 \mathrm{~Hz}, 4 \mathrm{H}), 7.60(\mathrm{~d}, J=8.44 \mathrm{~Hz}$, $4 \mathrm{H}), 7.44(\mathrm{~d}, J=3.55 \mathrm{~Hz}, 4 \mathrm{H}), 7.33(\mathrm{~d}, J=4.52 \mathrm{~Hz}, 4$ $\mathrm{H}), 7.17(\mathrm{dd}, J=4.95,3.61 \mathrm{~Hz}, 4 \mathrm{H}) \cdot{ }^{13} \mathrm{C} \mathrm{NMR}(100 \mathrm{MHz}$,

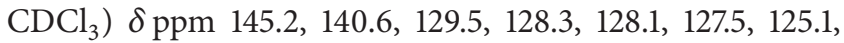
124.1, 124.0, 122.6, 118.1, 110.3. HR-ESI-MS: $m / z$ calcd for [M $+\mathrm{H}]^{+}=\mathrm{C}_{46} \mathrm{H}_{28} \mathrm{~N}_{2} \mathrm{~S}_{4}$ 737.1213; found 737.1210. Anal. calcd. for $\mathrm{C}_{46} \mathrm{H}_{28} \mathrm{~N}_{2} \mathrm{~S}_{4}$ : C, 75.01; H, 3.83; N, 3.80; S, 17.36. Found: C, 74.99; H, 3.80; N, 3.77; S, 17.32 .

\section{Competing Interests}

The authors declare no competing financial interests. 


\section{Acknowledgments}

The authors are thankful for the support of the Chemistry Department, Faculty of Science University Malaya, Kuala Lumpur, Malaysia, and for financial support from the Long Term Research Grant Scheme (LRGS) (LR003-2011A), High Impact Research Grant (HIR) (UM.C/625/1/HIR/208) (J-21001-73865), and Postgraduate Research Grant (PPP) (PG021-2013A).

\section{References}

[1] A. Mishra and P. Bäuerle, "Small molecule organic semiconductors on the move: promises for future solar energy technology," Angewandte Chemie International Edition, vol. 51, no. 9, pp. 2020-2067, 2012.

[2] H. Klauk, Organic Electronics: Materials, Manufacturing, and Applications, John Wiley \& Sons, New York, NY, USA, 2006.

[3] K. Müllen and U. Scherf, Eds., Organic Light Emitting Devices: Synthesis, Properties and Applications, Wiley-VCH, Weinheim, Germany, 2006.

[4] T. J. J. Muller and U. H. F. Bunz, Functional Organic Materials: Syntheses, Strategies and Applications, Wiley-VCH, Weinheim, Germany, 2007.

[5] Z. H. Kafafi, Organic Electroluminescence, CRC Press, New York, NY, USA, 2005.

[6] M. M. Haley and R. R. Tykwinski, Carbon-Rich Compounds: from Molecules to Materials, John Wiley \& Sons, New York, NY, USA, 2006.

[7] T. W. Kelley, P. F. Baude, C. Gerlach et al., "Recent progress in organic electronics: materials, devices, and processes," Chemistry of Materials, vol. 16, no. 23, pp. 4413-4422, 2004.

[8] S. R. Forrest and M. E. Thompson, "Introduction: organic electronics and optoelectronics," Chemical Reviews, vol. 107, no. 4, pp. 923-925, 2007.

[9] M. Bendikov, F. Wudl, and D. F. Perepichka, "Tetrathiafulvalenes, oligoacenenes, and their buckminsterfullerene derivatives: the brick and mortar of organic electronics," Chemical Reviews, vol. 104, no. 11, pp. 4891-4945, 2004.

[10] Y. Shirota and H. Kageyama, "Charge carrier transporting molecular materials and their applications in devices," Chemical Reviews, vol. 107, no. 4, pp. 953-1010, 2007.

[11] W. Wu, Y. Liu, and D. Zhu, " $\pi$-Conjugated molecules with fused rings for organic field-effect transistors: design, synthesis and applications," Chemical Society Reviews, vol. 39, no. 5, pp. 14891502, 2010.

[12] N. J. Tao, "Electron transport in molecular junctions," Nature nanotechnology, vol. 1, no. 3, pp. 173-181, 2006.

[13] J. C. Cuevas and E. Scheer, Molecular Electronics: An Introduction to Theory and Experiment, vol. 1, World Scientific, River Edge, NJ, USA, 2010.

[14] J. V. Grazulevicius, P. Strohriegl, J. Pielichowski, and K. Pielichowski, "Carbazole-containing polymers: synthesis, properties and applications," Progress in Polymer Science, vol. 28, no. 9, pp. 1297-1353, 2003.

[15] J.-F. Morin, M. Leclere, D. Adès, and A. Siove, "Polycarbazoles: 25 years of progress," Macromolecular Rapid Communications, vol. 26, no. 10, pp. 761-778, 2005.

[16] N. Blouin and M. Leclerc, "Poly(2,7-carbazole)s: structureproperty relationships," Accounts of Chemical Research, vol. 41, no. 9, pp. 1110-1119, 2008.
[17] P. L. T. Boudreault, J. F. Morin, and M. Leclerc, "Synthesis of poly(2,7-carbazole)s and derivatives," in Design and Synthesis of Conjugated Polymers, pp. 205-226, 2010.

[18] S.-I. Kato, H. Noguchi, A. Kobayashi, T. Yoshihara, S. Tobita, and Y. Nakamura, "Bicarbazoles: systematic structure-property investigations on a series of conjugated carbazole dimers," Journal of Organic Chemistry, vol. 77, no. 20, pp. 9120-9133, 2012.

[19] A. Mishra, C.-Q. Ma, and P. Bäuerle, "Functional oligothiophenes: molecular design for multidimensional nanoarchitectures and their applications," Chemical Reviews, vol. 109, no. 3, pp. 1141-1176, 2009.

[20] I. F. Perepichka and D. F. Perepichka, Handbook of ThiopheneBased Materials: Applications in Organic Electronics and Photonics, Wiley Online Library, 2009.

[21] J.-F. Morin, N. Drolet, Y. Tao, and M. Leclerc, "Syntheses and characterization of electroactive and photoactive 2,7-carbazolenevinylene-based conjugated oligomers and polymers," Chemistry of Materials, vol. 16, no. 23, pp. 4619-4626, 2004.

[22] M. Belletête, J.-F. Morin, M. Leclerc, and G. Durocher, "A theoretical, spectroscopic, and photophysical study of 2,7carbazolenevinylene-based conjugated derivatives," The Journal of Physical Chemistry A, vol. 109, no. 31, pp. 6953-6959, 2005.

[23] J. Lu, P. F. Xia, P. K. Lo, Y. Tao, and M. S. Wong, "Synthesis and properties of multi-triarylamme-substituted carbazole-based dendrimers with an oligothiophene core for potential applications in organic solar cells and light-emitting diodes," Chemistry of Materials, vol. 18, no. 26, pp. 6194-6203, 2006.

[24] M. Melucci, L. Favaretto, C. Bettini et al., "Liquid-crystalline rigid-core semiconductor oligothiophenes: influence of molecular structure on phase behaviour and thin-film properties," Chemistry-A European Journal, vol. 13, no. 36, pp. 1004610054, 2007.

[25] T. Khanasa, N. Prachumrak, R. Rattanawan et al., "Bis(carbazol9-ylphenyl) aniline end-capped oligoarylenes as solutionprocessed nondoped emitters for full-emission color tuning organic light-emitting diodes," The Journal of Organic Chemistry, vol. 78, no. 13, pp. 6702-6713, 2013.

[26] N. Koumura, Z.-S. Wang, S. Mori, M. Miyashita, E. Suzuki, and K. Hara, "Alkyl-functionalized organic dyes for efficient molecular photovoltaics," Journal of the American Chemical Society, vol. 128, no. 44, pp. 14256-14257, 2006.

[27] Z.-S. Wang, N. Koumura, Y. Cui et al., "Hexylthiophene-functionalized carbazole dyes for efficient molecular photovoltaics: tuning of solar-cell performance by structural modification," Chemistry of Materials, vol. 20, no. 12, pp. 3993-4003, 2008.

[28] N. Koumura, Z.-S. Wang, M. Miyashita et al., "Substituted carbazole dyes for efficient molecular photovoltaics: long electron lifetime and high open circuit voltage performance," Journal of Materials Chemistry, vol. 19, no. 27, pp. 4829-4836, 2009.

[29] Y. Ooyama, Y. Shimada, S. Inoue et al., "New molecular design of donor- $\pi$-acceptor dyes for dye-sensitized solar cells: control of molecular orientation and arrangement on $\mathrm{TiO}_{2}$ surface," New Journal of Chemistry, vol. 35, no. 1, pp. 111-118, 2011.

[30] W. Lee, N. Cho, J. Kwon, J. Ko, and J.-I. Hong, "New organic dye based on a 3,6-disubstituted carbazole donor for efficient dyesensitized solar cells," Chemistry-An Asian Journal, vol. 7, no. 2, pp. 343-350, 2012.

[31] C. Chen, J.-Y. Liao, Z. Chi et al., "Metal-free organic dyes derived from triphenylethylene for dye-sensitized solar cells: tuning of the performance by phenothiazine and carbazole," Journal of Materials Chemistry, vol. 22, no. 18, pp. 8994-9005, 2012. 
[32] T. Sudyoadsuk, S. Pansay, S. Morada et al., "Synthesis and characterization of D-D- $\pi$-A-type organic dyes bearing carbazolecarbazole as a donor moiety (D-D) for efficient dye-sensitized solar cells," European Journal of Organic Chemistry, vol. 2013, no. 23, pp. 5051-5063, 2013.

[33] G. Wei, R. R. Lunt, K. Sun, S. Wang, M. E. Thompson, and S. R. Forrest, "Efficient, ordered bulk heterojunction nanocrystalline solar cells by annealing of ultrathin squaraine thin films," Nano Letters, vol. 10, no. 9, pp. 3555-3559, 2010.

[34] V. Coropceanu, J. Cornil, D. A. da Silva Filho, Y. Olivier, R. Silbey, and J.-L. Brédas, "Charge transport in organic semiconductors," Chemical Reviews, vol. 107, no. 4, pp. 926-952, 2007.

[35] B. Walker, A. B. Tamayo, X.-D. Dang et al., "Nanoscale phase separation and high photovoltaic efficiency in solutionprocessed, small-molecule bulk heterojunction solar cells," Advanced Functional Materials, vol. 19, no. 19, pp. 3063-3069, 2009.

[36] B. Walker, C. Kim, and T.-Q. Nguyen, "Small molecule solutionprocessed bulk heterojunction solar cells," Chemistry of Materials, vol. 23, no. 3, pp. 470-482, 2011.

[37] N. Miyaura and A. Suzuki, "Palladium-catalyzed cross-coupling reactions of organoboron compounds," Chemical Reviews, vol. 95, no. 7, pp. 2457-2483, 1995.

[38] I. P. Beletskaya and A. V. Cheprakov, "Copper in cross-coupling reactions: the post-Ullmann chemistry," Coordination Chemistry Reviews, vol. 248, no. 21-24, pp. 2337-2364, 2004.

[39] B. R. Kaafarani, A. O. El-Ballouli, R. Trattnig et al., "Bis(carbazolyl) derivatives of pyrene and tetrahydropyrene: synthesis, structures, optical properties, electrochemistry, and electroluminescence," Journal of Materials Chemistry C, vol. 1, no. 8, pp. 1638-1650, 2013.

[40] B. E. Koene, D. E. Loy, and M. E. Thompson, "Asymmetric triaryldiamines as thermally stable hole transporting layers for organic light-emitting devices," Chemistry of Materials, vol. 10, no. 8, pp. 2235-2250, 1998.

[41] P. Schrögel, A. Tomkevičiene, P. Strohriegl, S. T. Hoffmann, A. Köhler, and C. Lennartz, "A series of CBP-derivatives as host materials for blue phosphorescent organic light-emitting diodes," Journal of Materials Chemistry, vol. 21, no. 7, pp. 22662273, 2011.

[42] C. Chi and G. Wegner, "Chain-length dependence of the electrochemical properties of conjugated oligofluorenes," Macromolecular Rapid Communications, vol. 26, no. 19, pp. 1532-1537, 2005.

[43] J. Pommerehne, H. Vestweber, W. Guss et al., "Efficient two layer LEDs on a polymer blend basis," Advanced Materials, vol. 7, no. 6, pp. 551-554, 1995.

[44] K. Hara, K. Miyamoto, Y. Abe, and M. Yanagida, "Electron transport in coumarin-dye-sensitized nanocrystalline $\mathrm{TiO}_{2}$ electrodes," The Journal of Physical Chemistry B, vol. 109, no. 50, pp. 23776-23778, 2005.

[45] H. Cao, J. Ma, G. Zhang, and Y. Jiang, "Borole/thiophene cooligomers and copolymers with quinoid structures and biradical characters," Macromolecules, vol. 38, no. 4, pp. 1123-1130, 2005.

[46] S. T. Hoffmann, P. Schrögel, M. Rothmann, R. Q. Albuquerque, P. Strohriegl, and A. Köhler, "Triplet excimer emission in a series of $4,4^{\prime}$-bis( $N$-carbazolyl)-2,2' -biphenyl derivatives," The Journal of Physical Chemistry B, vol. 115, no. 3, pp. 414-421, 2011.

[47] M. Belletête, M. Bédard, M. Leclerc, and G. Durocher, "Ground and excited state properties of carbazole-based dyads: correlation with their respective absorption and fluorescence spectra,"
Journal of Molecular Structure: THEOCHEM, vol. 679, no. 1-2, pp. 9-15, 2004.

[48] L. Yang, J.-K. Feng, A.-M. Ren, and J.-Z. Sun, "The electronic structure and optical properties of carbazole-based conjugated oligomers and polymers: a theoretical investigation," Polymer, vol. 47, no. 4, pp. 1397-1404, 2006.

[49] K. R. Radke, K. Ogawa, and S. C. Rasmussen, "Highly fluorescent oligothiophenes through the incorporation of central dithieno[3, 2-b: 2', 3'-d]pyrrole units," Organic Letters, vol. 7, no. 23, pp. 5253-5256, 2005.

[50] I. B. Berlman, "Empirical correlation between nuclear conformation and certain fluorescence and absorption characteristics of aromatic compounds," The Journal of Physical Chemistry, vol. 74, no. 16, pp. 3085-3093, 1970.

[51] S.-I. Kato, S. Shimizu, A. Kobayashi, T. Yoshihara, S. Tobita, and Y. Nakamura, "Systematic structure-property investigations on a series of alternating carbazole-thiophene oligomers," The Journal of Organic Chemistry, vol. 79, no. 2, pp. 618-629, 2014.

[52] A. Hlel, A. Mabrouk, M. Chemek, I. Ben Khalifa, and K. Alimi, "A DFT study of charge-transfer and opto-electronic properties of some new materials involving carbazole units," Computational Condensed Matter, vol. 3, pp. 30-40, 2015.

[53] X. Lu, S. Fan, J. Wu, X. Jia, Z.-S. Wang, and G. Zhou, "Controlling the charge transfer in D-A-D chromophores based on pyrazine derivatives," The Journal of Organic Chemistry, vol. 79, no. 14, pp. 6480-6489, 2014.

[54] A. R. Murphy and J. M. J. Fréchet, "Organic semiconducting oligomers for use in thin film transistors," Chemical Reviews, vol. 107, no. 4, pp. 1066-1096, 2007.

[55] S. Allard, M. Forster, B. Souharce, H. Thiem, and U. Scherf, "Organic semiconductors for solution-processable field-effect transistors (OFETs)," Angewandte Chemie-International Edition, vol. 47, no. 22, pp. 4070-4098, 2008.

[56] P. M. Beaujuge and J. M. J. Fréchet, "Molecular design and ordering effects in $\pi$-functional materials for transistor and solar cell applications," Journal of the American Chemical Society, vol. 133, no. 50, pp. 20009-20029, 2011.

[57] N. Acar, J. Kurzawa, N. Fritz et al., "Phenothiazine-pyrene dyads: photoinduced charge separation and structural relaxation in the CT state," Journal of Physical Chemistry A, vol. 107, no. 45, pp. 9530-9541, 2003.

[58] C. Lee, W. Yang, and R. G. Parr, "Development of the ColleSalvetti correlation-energy formula into a functional of the electron density," Physical Review B, vol. 37, no. 2, pp. 785-789, 1988.

[59] S. Tretiak and S. Mukamel, "Density matrix analysis and simulation of electronic excitations in conjugated and aggregated molecules," Chemical Reviews, vol. 102, no. 9, pp. 3171-3212, 2002.

[60] Y. Wu, H. Guo, T. D. James, and J. Zhao, "Enantioselective recognition of mandelic acid by a 3,6-dithiophen-2-yl-9Hcarbazole-based chiral fluorescent bisboronic acid sensor," The Journal of Organic Chemistry, vol. 76, no. 14, pp. 5685-5695, 2011.

[61] S. H. Tucker, "Iodination in the carbazole series," Journal of the Chemical Society, vol. 1, pp. 548-553, 1926.

[62] D. Kim, J. K. Lee, S. O. Kang, and J. Ko, "Molecular engineering of organic dyes containing $\mathrm{N}$-aryl carbazole moiety for solar cell," Tetrahedron, vol. 63, no. 9, pp. 1913-1922, 2007. 

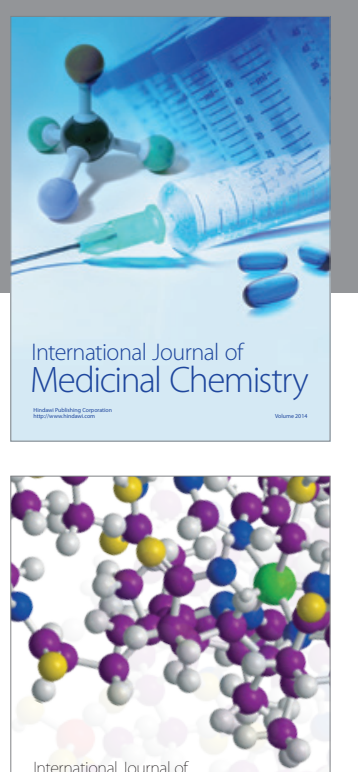

Carbohydrate Chemistry

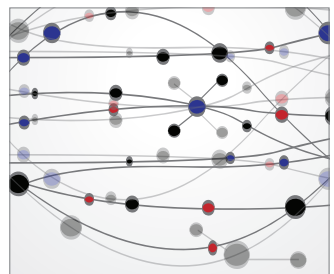

The Scientific World Journal
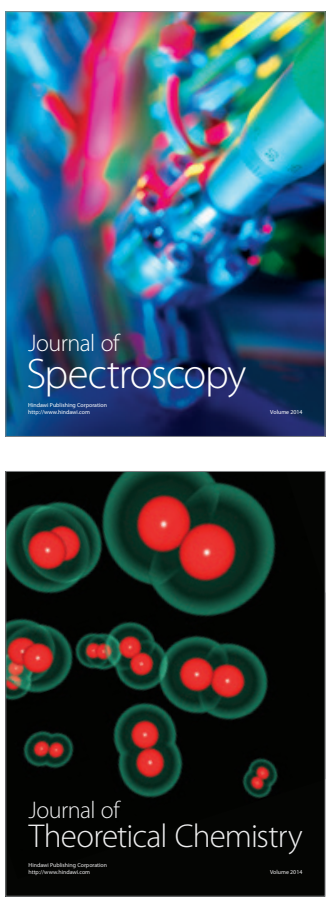
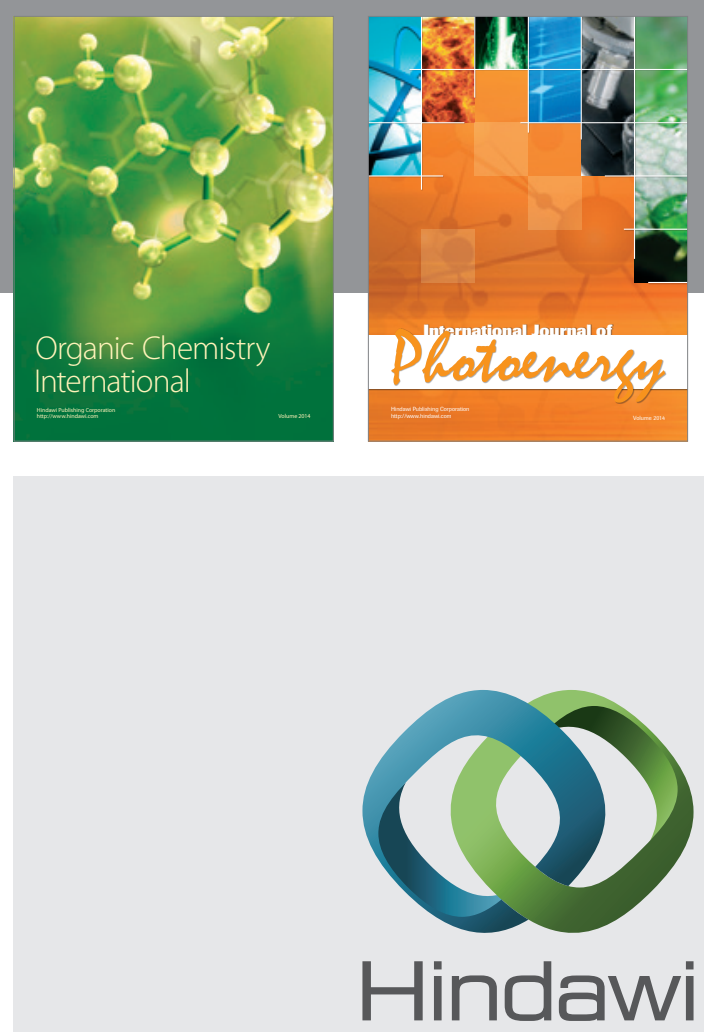

Submit your manuscripts at

http://www.hindawi.com

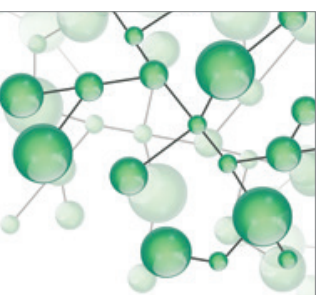

International Journal of

Inorganic Chemistry

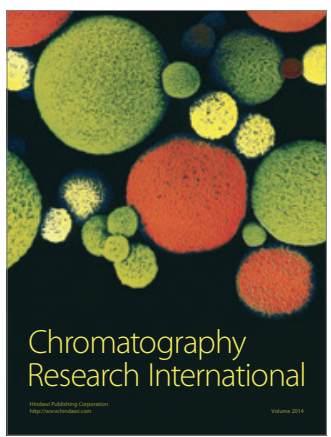

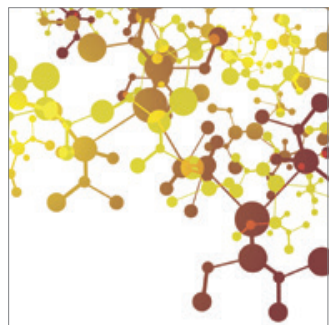

Applied Chemistry
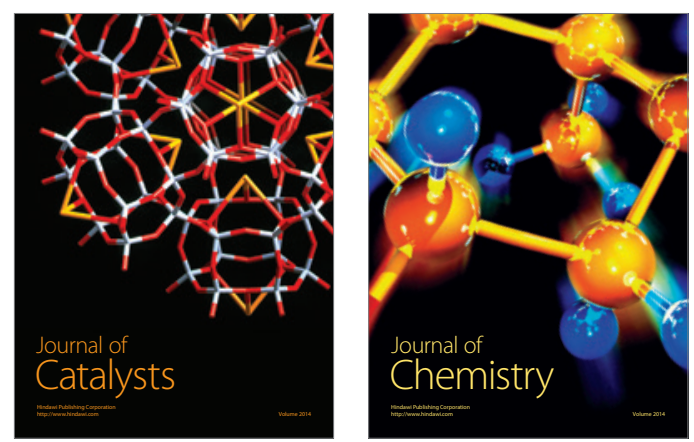
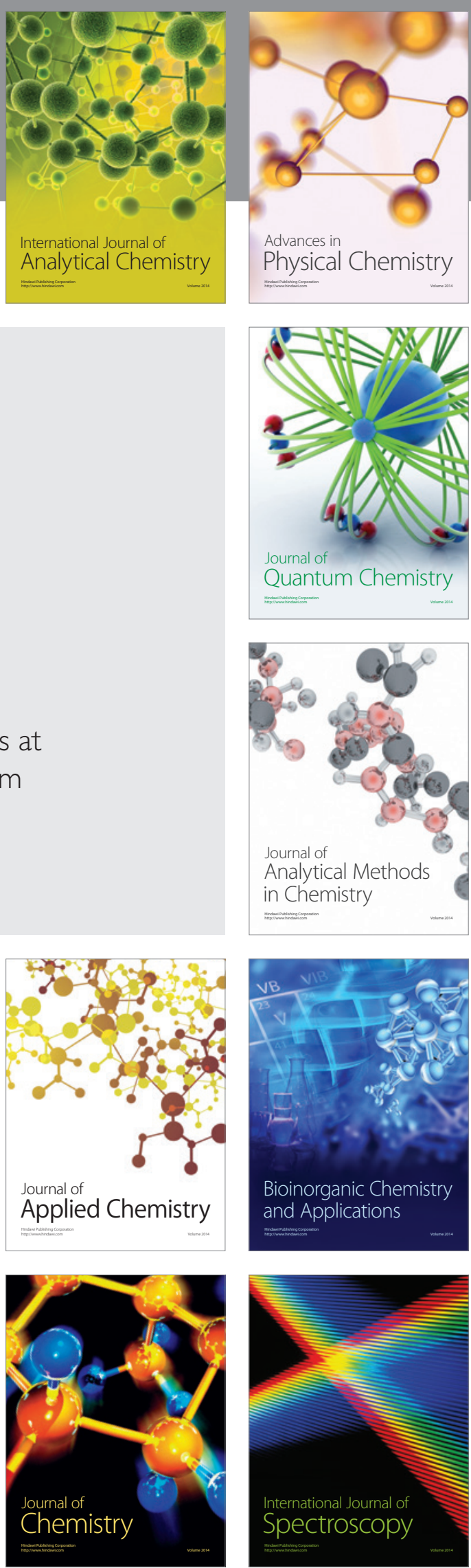